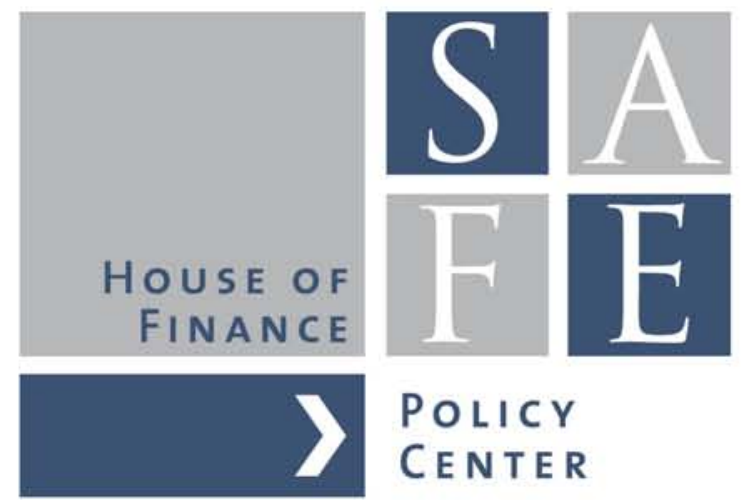

Helmut Siekmann

\title{
The Legal Framework for the European System of Central Banks
}

White Paper No. 26

SAFE I Sustainable Architecture for Finance in Europe A cooperation of the Center for Financial Studies and Goethe University Frankfurt 
This paper previously appeared, under the same title, in the IMFS WORKING PAPER SERIES as Working Paper No. 89 (2015).

\section{Institute for Monetary and Financial Stability}

Goethe University Frankfurt

House of Finance

Theodor-W.-Adorno-Platz 3

D-60323 Frankfurt am Main

www.imfs-frankfurt.de | info@imfs-frankfurt.de 


\title{
THE LEGAL FRAMEWORK FOR THE EUROPEAN SYSTEM OF CENTRAL BANKS
}

\author{
Helmut Siekmann
}

\begin{abstract}
The Treaty of Maastricht imposed the strict obligation on the European Union (EU) to establish an economic and monetary union, now Article 3(4) TEU. This economic and monetary union is, however, not designed as a separate entity but as an integral part of the EU. The single currency was to become the currency of the EU and to be the legal tender in all Member States unless an exemption was explicitly granted in the primary law of the EU, as in the case of the UK and Denmark. The newly admitted Member States are obliged to introduce the euro as their currency as soon as they fulfil the admission criteria. Technically, this has been achieved by transferring the exclusive competence for the monetary policy of the Member States whose currency is the euro on the EU, Article 3(1)(c) TFEU and by bestowing the euro with the quality of legal tender, the only legal tender in the EU, Article
\end{abstract} 128(1) sentence 3 TFEU.

Consequently, the primary law systematically only speaks of economic policy or monetary policy which is the task of the Eurosystem, consisting of the ECB and the central banks of the Member States whose currency is the euro. The national central banks of all Member States together with the ECB constitute the European System of Central Banks (ESCB), which does not not have legal personality, Article 282(1) TFEU. Only the ECB is established as an institution and is granted legal personality, Article 282(3) TFEU. It is noteworthy that the Member States per se do not participate in the ESCB, only national central banks which are also the sole subscribers and holders of the capital of the ECB, Article 28.2. of the Statute of the ESCB and the ECB.

General economic policy is not a task of the EU, but has been retained by the Member States. Exceptions have to be provided explicitly in the primary law. From this, it follows that economic policy - to be strictly differentiated from monetary policy, pursuant to Article 119 TFEU - is not a task of the ECB. In particular, fiscal responsibility in general and responsibility for the consequences of excessive government deficits have remained with the 
Member States. Primary and secondary EU law, however, contain a host of rules to prevent excessive debt and deficits on the part of Member States, the so-called Stability and Growth Pact (SGP), which has been amended several times in the course of the crisis.

Price stability has been set as the "primary objective”, for monetary policy in general, Article 119(2) sentence 1, Article 219(1) sub-paragraph 2 TFEU and in Articles 127(1) and 282(2) sentence 2 TFEU for monetary policy in a narrow sense. The term "price stability” has to be interpreted - in contrast to the statements of the ECB - as close to zero per cent inflation. Primary law does not contain an "inflation target" which has to be attained, nor does it specify the prevention of deflation. To safeguard the primary objective, a comprehensive guarantee of the personal, institutional, and financial independence of the ESCB, the ECB, and the members of its organs has been provided for in the primary law.

Exit from the Monetary Union while remaining a Member State of the EU is not possible, as a separate "Monetary Union” entity does not exist. Consequently, the Treaty of Lisbon provided only for withdrawal from the EU as a whole. It can now be done by simple notification of the European Council, Article 50(1) and (2) sentence 1 TEU. This new provision has to be judged as conclusive. It is also consistent with the fundamental architecture of the EU which did not establish the Monetary Union as a separate entity. Hence, an institution aside from the EU, one which can be joined or left, does not exist. This is also the reason why, technically, the euro is introduced in a Member States whose currency has heretofore not been the euro by revoking an exemption, as in the case of Greece by Council Decision 2000/427/EC. It is legally not possible to reverse this act, not even in the case of fraud or misrepresentation, which was subsequently disclosed in the case of Greece. Furthermore, neither the general rules of the law of nations, nor the special rules on the termination of treaties are applicable, as specific, conclusive rules exist. The conditions to apply this are not met, as in the case of the clausula rebus sic stantibus or Article 62 of the Vienna Convention on the Law of Treaties. The introduction of a parallel currency is prohibited by Article 128(1) sentence 3 TFEU.

Neither the organs of the EU nor the Member States can legally grant an exemption or a waiver to these rules. If a new currency in substitution of the euro or parallel to it is introduced in deviation from these rules, there will be severe consequences. All claims denominated in euro will remain in euro, regardless of the legal system by which they have 
been set up and regardless of national legislation. As long as the country remains in the EU, it has forfeited this part of its sovereignty.

\section{THE EUROPEAN ECONOMIC AND MONETARY UNION}

\subsection{FORMATION OF THE EUROPEAN ECONOMIC AND MONETARY UNION ${ }^{1}$}

A report, delivered in February 1969 by the then French Vice-President of the European Commission and later Prime Minister Raymond Barre, proposed greater co-ordination of economic policies and closer monetary co-operation. ${ }^{2}$ These two proposals were eventually realised by the Treaty of Maastricht, ${ }^{3}$ but to a different extent. Since then, the "exclusive competence" "for monetary policy for the Member States whose currency is the euro" is vested in the European Union (EU), ${ }^{4}$ but not the competence for economic policy, which has remained, in principle, with the Member States, although with an obligation of close cooperation. This result is laid down in Article 119(1) TFEU $^{5}$ for all Member States, and intensified by Article 136(1) for the Member States whose currency is the euro. Furthermore, the details of the rules for the European System of Central Banks (ESCB) and its competences, especially Article 127(1) and (2) TFEU, are determined by it. ${ }^{6}$

To date, it has remained an open and debated question whether a common economic policy would have been an essential pre-requisite for the functioning of the Monetary Union, or whether a monetary union (automatically) leads to a common economic policy. This

1 For a more comprehensive description, see HELMUT SIEKMANN (2012). Some of the following is derived from that work.

2 Commission Memorandum to the Council on the co-ordination of economic policies and monetary cooperation within the Community, submitted on 12 February 1969, Bulletin of the EC No. 1, 1971. A predecessor was the "Marjolin Memorandum" of the Commission, see HANSPETER K. SCHELler (2006), p. 17; ANDRÉ SzÁs (1999), pp. 8, 9. Upon the basis of the "Barre Report”, a more specified three-step plan was developed by the Prime Minister of Luxembourg, Pierre Werner. The final design was framed in a plan delivered by the then President of the Commission, Jacques Delors; see HELMUT SiEKMANN (2013), Einführung [introduction], No 10-26.

3 Signed 7 February 1992, Official Journal, 29 July 1992, C 191/1.

4 Now Article 3(1)(c) TFEU.

5 Consolidated versions of the Treaty on European Union and the Treaty on the Functioning of the European Union, Official Journal of 26 October 2012, C 326/01.

6 More in Section 1.4. below. 
discussion is frequently continued under the label of the necessity of a closer "political union” for the functioning of the Monetary Union. ${ }^{7}$

The Treaty of Maastricht introduced the Economic and Monetary Union de facto without fully-fledged political integration. The euro was created as a currency without a state. ${ }^{8}$ This was done fully aware of the fact that many critics, to wit, economists, considered this procedure to be taking the second step before the first. ${ }^{9}$ Even if this closer political union was not realised from the beginning, the single currency nonetheless both extends and completes the "single market". To this extent, it has worked as "integration via the economy”, ${ }^{10}$ even in view of the financial turbulences of the past years.

The Treaty of Maastricht amended the primary law of the European Economic Community (EEC) to the extent that all institutional, procedural, and substantive provisions for the new common currency and its functioning were already in force before the European System of Central Banks (ESCB) and its main actor, the European Central Bank (ECB), had effectively been set up. Even the statute for this system had already been formulated in all details by the Treaty of Maastricht and was attached to it as a protocol. ${ }^{11}$ As such, it is part of the primary law of the EU, Article 51 TEU, and these provisions have become the cornerstones of the European Monetary Union. ${ }^{12}$ The amendment procedure is, however, simplified to a certain extent in comparison to the other parts of the primary law of the EU, Article 40 Statute ESCB/ECB.

PAUl DE GRAUWE (2010), p. 31.

Critical: Deutsche Bundesbank, Monthly Bulletin (Monatsbericht), February 1992, p. 53; PETER J. TETTINGER (1992), p. 10, with further references; defending the creation of the Monetary Union at an early stage GERT NICOLAYSEN (1993), pp. 10-18. A topic which was treated by OTMAR Issing, leading economist, former member of the board of the Deutsche Bundesbank and of the Executive Board of the ECB, see, e.g., OTMAR ISSING (2008a); IDEM (2008b), p. 297.

9 See, for example, J.E. MEADE (1957), p. 388; the references given by GERT NICOLAYSEN (1993), p. 7 note 2; see, also CHRISTOPH DEGENHART (2012), p. 158 et seq; for a balanced discussion with mild scepticism, see OTMAR ISSING (2008c), pp. 227-236.

Described by OTMAR Issing (2008b), p. 299 et seq.

11 Protocol (No 4) on the Statute of the European System of Central Banks and of the European Central Bank, Official Journal C 326/230 of 26 October 2010; afterwards referred to as "Statute ESCB/ECB".

12 Now Part Three, Title VIII of the Treaty on the Functioning of the European Union (TFEU), consolidates version, Official Journal, 30 March 2010, C 83/1 (96). 


\subsection{The Transfer of MONETARy Authority to THE EUROPEAN UniON}

\subsubsection{Monetary Policy as Exclusive Competence of the Union}

The Treaty of Maastricht introduced the obligation for the EU (EEC) and the Member States to create a single currency. It started from the premise that the new currency was to become the currency of the European Union as it originally assumed that - at least in the medium term - all Member States would introduce the euro. ${ }^{13}$ In other words, the Member States had to give up a substantial part of their sovereign powers: ${ }^{14}$ the "right to create, to define, and to re-organise a national monetary system". They also lost "the right to conduct an independent monetary policy". ${ }^{15}$ The "exclusive competence" for "monetary policy" has been vested in the European Union; but only for the Member States whose currency is the euro, pursuant to Article 3(1)(c) TFEU. This means that they have lost all powers in this field; unconditionally and irrevocably, regardless of the specific actions of the Union. The loss of competences is total. $^{16}$

The power to create money in the legal sense of the word ("legal tender") had been widely considered to be a sovereign right of a ruler (ius cudendae monetae), ${ }^{17}$ but it is not indispensable for a qualification as (sovereign) state, as history shows. ${ }^{18}$ There have always been sovereign entities which did not exercise this right and did not create a currency of their own, or which acknowledged more than one currency as legal tender, or left it to the several entities of a federal system to exercise this right on their own. In any case, the general

13 The wording of Article 3 (4) TEU is somewhat murky: "The Union shall establish an economic and monetary union whose currency is the euro". The EMU has been established by the Treaty itself but the introduction of the single currency needed additional measures; see also European Commission (2006).

OTMAR ISSING (2008b), p. 301.

CHARles PROCTOR (2012), no. 31.09 and 31.10.

16 Literal translation of CHRISTIAN CALLIESS (2011b), Article 2 margin no. 9 with further references.

17 Permanent Court of International Justice - PCIJ, Judgment of July 12th, 1929, case concerning the payment of various Serbian loans issued in France, Publications of the Permanent Court of International Justice, Series A - Nos. 20/21, p. 44: "It is indeed a generally accepted principle that a State is entitled to regulate its own currency." The same wording is used in the judgment of the same day on the case concerning the payment in gold of Brazilian federal loans contracted in France, id. p. 122. See, in detail, F.A. MANN (1992), pp. 14, 16 \& 18; Fred Hirsch (1967), p. 30; HERRMANn FöGEN (1969), p. 35; Robert A. MundeLL (1997), p. 16 with a detailed description of the development in history pp. 9-15; RosA MARÍA LASTRA (2006), p. 16; FrANK VISCHER (2010), section 15 II; CHRISTOPH HERRMANN (2010a), pp. 99-102 with further references; CHARLES PROCTOR (2012), p. 526; tentatively German Federal Constitutional Court [GFCC] of 20 July 1954, BVerfGE [Decisions of the Federal Constitutional Court] 4 [volume], 60 [page]. HeLmut SiEKMANN (2014), Article 88 margin no. 107; and Section 3.3. below. 
decision to transfer this sovereign right to the EU was taken and the judiciary did not object. $^{19}$ For the state theory of money, the state is even a pre-requisite for the existence of money, since money is considered only as a creation of the legal system and is defined by an arbitrary act of the state. ${ }^{20}$

\subsubsection{The Obligation to Introduce the Euro}

The primary law of the Union expects all Member States to introduce the euro once they fulfil the convergence criteria. ${ }^{21}$ When negotiating the Treaty of Maastricht, it became, however, clear that not all Member States were prepared to introduce the euro as their currency. Some did not want to accept the obligation to introduce the new currency, others were not yet ready to take this step. As a result, the United Kingdom obtained a provision which allowed it to refrain from entering the third stage of the European Monetary Union (EMU) even if it fulfilled the convergence criteria (opt-out clause). ${ }^{22}$ As the Treaty was rejected by a referendum in Denmark, this country was also granted an exemption as well. ${ }^{23}$ For most new Member States, mainly from eastern-central Europe, custom-made rules for the transition period were adopted in the respective treaties admitting them to the Union. They were signed by all the Member States and have the quality of primary law of the Union. Only Sweden was neither granted an exemption nor completed the admittance procedure to the euro despite the general obligation to do so. ${ }^{24}$ This is also the reason why the obligation to set

19 BVerfGE 89, 155; 97, 350; HeLmut SiEKMANN (2014), Article 88 margin no. 30, 33.

20 GEORG FRIEDRICH KNAPP (1905), pp. 1, 20. This insight had been publicised almost a generation earlier by a much less famous author: GuSTAV HARTMANN (1868), p. 12, 58, 64, 112: "Da der Satz, daß eine bestimmte für unseren Verkehr eigens geschaffene Münzsorte 'Geld' (...) sein sollte, juristisch nur auf einen besonderen Act unserer Rechtsordnung zurückgeführt werden kann.”

21 Now Article 3(4) TEU, 119(2), 140(1) TFEU in conjunction with Protocol (No 13) on the convergence criteria; without reservation: ChARLES PROCTOR (2012), margin no. 31.44; BernARD KeMPEN (2012), Article 119 margin no. 6; in favour of a strict interpretation, see WERNER HEUN (1998), p. 866.

22 Protocol (No 15) on certain provisions relating to the United Kingdom of Great Britain and Northern Ireland, Official Journal of 26 October 2010, C 326/284: “1. Unless the United Kingdom notifies the Council that it intends to adopt the euro, it shall be under no obligation to do so. (...) 3. The United Kingdom shall retain its powers in the field of monetary policy according to national law."

23 The exemption had the effect that all Articles and provisions of the Treaty and the Statute of ECSB/ECB referring to a "derogation" should be applicable to Denmark. The admission procedure of Article 140 TFEU should only be initiated at the request of Denmark, No 1 and 2 of the Protocol (No 16) on certain provisions relating to Denmark, Official Journal of 26 October 2010, C 326/287. More details Section 3.1 below. 
up the Monetary Union was retained as a permanent duty even after the revisions of the Treaties although it already had been established. ${ }^{25}$

\subsubsection{The Legal Formation of Two Groups of Member States}

As it was initially not envisaged to have permanently - or for a longer period of time - two classes of Member States - those whose currency is the euro and those which have another currency - no specific clauses in the Treaties dealt with this situation. First, the fundamental revision of the primary law of the Union by the Treaty of Lisbon ${ }^{26}$ entering into force in 2009 led to the "official" recognition of the two groups of Member States, despite the fact that this had been considered to be highly questionable before:

- A special section was inserted into the Treaty on the Functioning of the European Union (TFEU) with "provisions specific to Member States whose currency is the euro". ${ }^{27}$ Semi-officially, they are called the "euro area” or "eurozone”. Their representatives in the organs and other institutions of the EU are referred to as “euro group". 28

- The Member States whose currency is not the euro are now called by the primary law "Member States with a derogation", regardless of the reason why they did not introduce it. ${ }^{29}$ Most provisions regulating the Monetary Union are not applicable to them, Article 139(2) - (4) TFEU, and do not confer any rights or impose any obligations on them, Article 42(1) Statute ESCB/ECB. The “Member States with a derogation” (and their national central banks) are almost completely excluded from the decision-making process concerning the euro and

25 Article 3(5) TEU, cf. HeLmut SieKmann (2013), Article 3 margin nos. 9-12.

26 Signed on 13 December 2007 and entering into force on 1 January 2009, Official Journal C 306/1 of 17 December 2007; rectification on 30 April 2008, Official Journal C 111/56 of 6 May 2008; rectification on 27 November 2009, Official Journal C 209/1 of 6 May 2008.

27 Part three, Title VIII, Chapter 4, Articles 136-138 TFEU. Under certain provisions an "enhanced cooperation" had also been generally acknowledged, Part six, Title III, Articles 326-334 which served as justification for secondary legislation of the Union concerning only Member States whose currency is the euro aiming at preventing and solving financial crises.

29 Article 139(1) TFEU: "Member States in respect of which the Council has not decided that they fulfil the necessary conditions for the adoption of the euro shall hereinafter be referred as 'Member States with a derogation'." 
the actions taken by the ECB. ${ }^{30}$ This makes sense as they keep their monetary competences and retain their own currencies. ${ }^{31}$ The provisions of the primary law of the Union concerning economic policy, in specific Articles 119 - 126 TFEU, are, however, with minor exceptions ${ }^{32}$ still applicable to them. ${ }^{33}$

- The Treaty of Lisbon re-affirmed in view of this development as one of the aims of the Union, the wish "to establish an economic and monetary union whose currency is the euro" by inserting the new Article 3(4) TEU. ${ }^{34}$

\subsection{Safeguarding Price Stability}

\subsubsection{Price Stability as Objective of the EU}

Price stability is one of the many objectives which the EU is designated to pursue, Article 3(3) sub-paragraph 1 TEU. "Stable prices" are re-iterated as one of three "guiding principles" for the whole Economic and Monetary Union in Article 119(3) TFEU, but without granting this principle priority.

\subsubsection{Price Stability as Primary Objective of Monetary Policy}

For monetary policy, however, price stability is to be the "primary objective”, Article 119(2) sentence 1, Article 219(1) sub-paragraph 2 TFEU. Monetary policy is here understood in a wide sense, i.e., monetary policy in the narrow sense plus the exchange-rate policy which has to be thoroughly separated in theoretic analysis. How far this separation can be upheld in practical policy is another question. For the monetary policy in the narrow sense including the ESCB, the priority of price stability is repeated in Articles 127(1) and 282(2) sentence 2 TFEU.

Nevertheless, this does not imply that in this field the other objectives may be neglected. They only have to step back in the event of a conflict. Nevertheless, this distinct

30 Article 139(3) and (4) TFEU, Article 42.3. and Article 42.4. Statute ESCB/ECB.

31 ULRICH HäDE (2011), Article 139 at margin no. 4.

32 For example, deficit control pursuant Article 126 (9 and 11) and special wording for the UK.

33 See Bernard Kempen (2012), Article 139 margin no. 6.

34 See, for reference, footnote 25 above. 
priority was again called into question in the recent past in favour of growth and unemployment objectives by politicians and special interest groups. ${ }^{35}$ The priority of price stability is, however, unconditional, and it remains a strict obligation embedded in the primary law of the Union. It may not be watered down by means of interpretation. ${ }^{36}$ The framers of the Treaty of Maastricht did not want several objectives of the same rank, but a clear hierarchy of goals. ${ }^{37}$ This was decided in distinct contrast to the Federal Reserve Act where three objectives - not two as is often contended - of equal rank are prescribed: “maximum employment, stable prices, and moderate long-term interest rates”. 38

The general economic policies "in" the Union are only to be supported without prejudice to the primary objective, that of "price stability", Articles 127(1), 282(2) sentence 3 TFEU. Also the wording of Article 119(2) and (3) TFEU defining the general path of monetary and economic policy is revealing since it does not contain a growth or employment objective.

\subsubsection{The Content of the Term "Price Stability"}

The primary law does not provide a numeric value for price stability. Thus, almost as a dogma, the annual 2 per cent increase of the harmonised consumer price index, but slightly below this, in medium range, defined by the ECB as price stability, ${ }^{39}$ is widely used both by

35 For quite some time in the past price stability, growth, and (full) employment had been designated as objectives of equal rank, for details see: Sachverständigenr (1965), preface at no. 3; AlEX MöllER (1969), p. 91 et seq; HANS-HEINRICH HANSMEYER (1972), pp. 133-139, with some reservations; HELMUT SIEKMANN (1985), pp. 148, 151 et seq; Werner Heun (1998), p. 869; see, also, Markus Wiebel (1968), p. 904 et seq. WERNER HEUN (1998), p. 869.

37 JÖRn PiPKORN (1994), p. 285; JEAN-VICTOR LOUIS (1995), p. 59; RENÉ SMITS (1997), p. 399; HELMUT SIEKMANN (2013), Article 119 margin no. 98; partially disagreeing, see RAINER STADLER (1996), p. 101 et seq: relativisation by goals of Article 2 TEEC.

Federal Reserve Act, Section 2A. Monetary policy objectives: "The Board of Governors of the Federal Reserve System and the Federal Open Market Committee shall maintain long run growth of the monetary and credit aggregates commensurate with the economy's long run potential to increase production, so as to promote effectively the goals of maximum employment, stable prices, and moderate long-term interest rates [emphasis added].“

In October 1998 the Governing Council of the ECB defined price stability as "a year-on-year increase in the Harmonised Index of Consumer Prices (HICP) for the euro area of below 2\%" and added that price stability "was to be maintained over the medium term". The Governing Council confirmed this definition in May 2003 following a thorough evaluation of the ECB's monetary policy strategy. On that occasion, the Governing Council clarified that "in the pursuit of price stability, it aims to maintain inflation rates below but close to 2\% over the medium term”; European Central Bank, Press Report of 8 May 2003, Monthly 
economists and the public. ${ }^{40}$ Nevertheless, it must be kept in mind that this value is not a legal norm but a unilateral and, perhaps, arbitrary setting by an administrative body. In addition, it is not clear whether it conforms to the language of the primary law if taken seriously. This is also the reason why the majority of legal scholars in Germany understand the term "price stability" as a change of approximately zero per cent of the consumer price index. $^{41}$

For a long period of time, the definition of price stability was also not understood as a goal to be achieved but as a tolerable margin consistent with the price stability objective. More recently, not only in the media but also in official documents of the ECB, the "price stability” goal has been increasingly substituted by an "inflation goal” (Inflationsziel) ${ }^{42}$ which the ECB allegedly has to pursue. In the language of the primary law of the EU, however, not even the faintest trace of an "inflation target" can be found. The change in terminology is clearly used as an instrument to make the "unconventional" measures of the ECB appear "normal", with the further effect that such a "new normal" 43 should no longer be judged as illegal. The downside of such an "inflation goal" is that it does not take adequately into account the prevailing interest rates. From the microeconomic perspective, an inflation rate of 2 per cent has a considerably different effect depending on whether the interest rate for riskless investments is 3 per cent or 0.5 per cent. Striving for a situation of negative real interest rates over an extended period of time, as is in act at the moment, at least needs critical scrutiny.

Another problem which is not sufficiently treated in legal reasoning is the role of asset prices and their tendency to form fatal bubbles if not reined back appropriately by the

Bulletin, June 2003, p. 87; European Central Bank (2011b), p. 69; HANSPETER K. SCHELlER (2006), p. 80; see, also, Helmut SieKmann (2013), at Art. 119 TFEU margin no. 49; AleXANDer Thiele (2013), p. 30.

40 ECB Monthly Bulletin, October 2014, p. XIV: "Price stability: as defined by the Governing Council, a yearon-year increase in the HICP for the euro area of below 2\%. The Governing Council has also made it clear that, in the pursuit of price stability, it aims to maintain inflation rates below, but close to, $2 \%$ over the medium term."

41 Cf. Gert Nicolaysen (1993), p. 39; for references, see also HeLMUT SiEKMANN (2014), at Art. 88 margin no. 92. Also, non-German scholars preferred originally a margin of "less than 2\%” (RENÉ SMITS [1997], p.185, with further references).

42 See, for example, ECB vice president CONSTANCIO in an interview with Börsen-Zeitung of 11 September 2014: “(...) is the responsibility of monetary policy to reach the inflation goal”, available at: (http://www.ecb.europa.eu/press/inter/date/2014/html/sp140911.en.html); see, also, MARK ScHRÖERS (2014) citing the critique of Otmar Issing, who had, initially, shaped the monetary policy of the ECB.

43 HERMANN REMSPERGER (2013). 
competent authorities. This also holds for sovereign debt. The framers of the treaty of Maastricht did not envisage their detrimental effect on monetary and financial stability. From an economic point of view, the increase of prices that have to be paid for assets reveals also a form of inflation, asset price inflation. A record in stock market indices implies, for example, that the share of a corporation which can be bought for a given amount of money diminishes. This is also a loss of price stability and should be taken into account when exhorting the meaning of "price stability" in legal documents. ${ }^{44}$

\subsubsection{Safeguards to Guarantee the Objective "Price Stability”}

The essential role that the objective of "price stability" plays in the architecture of the Monetary Union is emphasised by the variety of safeguards included in the primary law to procure the achievement of this goal effectively:

- $\quad$ high admission standards (convergence criteria), Article 140 TFEU;

- comprehensive guarantee of independence of the monetary institutions, Articles 130, 131, 282(3) TFEU;

- $\quad$ no monetary financing of public sector, Article 123 TFEU;

- no privileged access of public sector entities to financial institutions, Article 124 TFEU;

- strict fiscal discipline of Member States and interdiction of excessive government debt, Article 126(1) TFEU; and

- no liability of the EU or Member States for the public sector debt of another Member State or assumption of financial commitments of the public sector of another Member State, Article 125(1) TFEU. ${ }^{45}$

44 Helmut Siekmann (2014), Article 88 margin no. 91.

45 Often labelled as the "no bail-out clause", which is, to a certain extent, at least misleading. 


\subsection{General Economic Policy not a Task of the EU}

\subsubsection{Separation of Monetary Policy and Economic Policy}

The primary law follows a clear and systematic separation between (general) economic policy, including fiscal policy, and monetary policy in Part Three, Title VIII TFEU. ${ }^{46}$ This systematic distinction is taken up in Article 119 (1) and (2) TFEU. ${ }^{47}$

\subsubsection{Competence for General Economic Policy with Member States}

Article 119(1) TFEU speaks of "the close coordination of Member States' economic policies". ${ }^{48}$ In Articles 119(2) and 127(1) sentence 2 TFEU, the "general economic policy in the Union” is referred to, but is distinctively not "of” the Union.

This statutory distinction between monetary policy and (general) economic policy and its diverging attribution is crucial for the whole architecture of the Economic and Monetary Union and its institutions. ${ }^{49}$ It discriminates the competences given to the Union from the powers remaining with the Member States. Such a distribution of competences presumes the separability of both areas of policy, which might be questionable from an economic perspective, ${ }^{50}$ but has become decisive for judging the support mechanisms set up by the EU and the Member States in the course of the crisis, ${ }^{51}$ and the unconventional measures of the

46

Emphasised by the GFCC: "According to Title VIII of the Treaty on the Functioning of the European Union and notwithstanding the special powers expressly assigned to the Union (e.g. Art. 121, 122, 126 TFEU), the responsibility for economic policy lies clearly with the Member States. In this field of economic policy, the European Union is - apart from individual exceptions that are in particular regulated in Part Three of the Treaty on the Functioning of the European Union - essentially limited to a coordination of Member States' economic policies" (judgment of 14 January 2014, cases: 2 BvR 2728/13, 2 BvR 2729/13, 2 BvR 2730/13, 2 BvR 2731/13, 2 BvE 13/13, available at:

[http://www.bundesverfassungsgericht.de/SharedDocs/Entscheidungen/EN/2014/01/rs20140114_2bvr27281 3en.html?nn=5403310] [OMT-judgment] margin no. 39, 63, 68; = BVerfGE 134, 366 [margin no. 39, 63, 68]).

48 Emphasis added. Furthermore, the Council is to "adopt measures specific to those Member States whose currency is the euro: (a) to strengthen the coordination and surveillance of their budgetary discipline; (b) to set out economic policy guidelines for them (...)", Article 136 (1) TFEU. Hermann-Josef Blanke (2012), p. 80 et seq; Helmut Siekmann (2013), Article 119 at margin no. 22, 24, 26.

50 AleXANDER THIELE (2014a), p. 694.

51 See HeLmut SieKMANN (2013), pp. 112 and 113:

- 2 May 2010, pledge of financial support for Greece by Member States through bilateral agreements, 
ECB. $^{52}$ Despite all interconnections and repercussions, a dividing line can be drawn with grey areas at the margins. ${ }^{53}$

The German Federal Constitutional Court (GFCC) delineates monetary policy in distinction from economic policy "according to the wording, structure, and purpose of the Treaties”. ${ }^{54}$ Concurring with the European Court of Justice, it discards acts which directly pursue economic policy objectives from monetary policy. Acts which only indirectly pursue monetary policy objectives are not to qualify as acts of monetary policy. ${ }^{55}$ Although this description seems to come close to a tautological transformation, it offers additional insight as it shifts the emphasis to the objectives of the respective policies which can be differentiated. Moreover, certain tools or instruments can clearly be labelled as economic policy: for example, "the granting of financial assistance", 56 or "the control of budgetary policy”. ${ }^{57}$ Finally, the relation of the act in question to other provisions and its embedding in an "overall relation" are also to be relevant. ${ }^{58}$

As a consequence, the ESCB and the ECB are barred from pursuing an economic policy of their own. ${ }^{59}$ This, of course, does not hinder them from considering the

Statement by the Eurogroup;

- 11 May 2010, general (temporary) support by the EU (European Financial Support Mechanism EFSM), Council Regulation (EU) No 407/2010 of 11 May 2010 establishing a European financial stabilisation mechanism, Official Journal of 12 May 2010 L 118/1;

- 7 June 2010, general (temporary) support by Member States (European Financial Stability Facility EFSF), EFSF Framework Agreement, draft of 20 May 2010, Executive Version of 7 June 2010;

- 11 July 2011/2 February 2012, (permanent) European Stability Mechanism (ESM).

For details, see HELMUT SiEKMANN (2015), Section 2.4.2. and 3.3.1.

53

, decision of 27 November 2012 in the proceedings Thomas Pringle v Government of Ireland Case C370/12 for a preliminary ruling under Article 267 TFEU from the Supreme Court (Ireland), Reports of Cases ECLI:EU:2012:756, margin no. 53, 92, 96, 108, 114. A very lax delineation is given by ALEXANDER THIELE (2014a), pp. 694-697: The monetary goal shall be decisive. The ECB commands wide discretionary power in defining it. Effects on government finances shall be irrelevant and it shall not be forbidden to undermine economic and fiscal policy. This attempt is clearly oriented at the goal to justify the debated and questionable measures of the ECB, see HELMUT SiEKMANN (2015), Section 2.

GFCC, OMT-judgment (footnote 47 above), margin no. 63.

Margin no. 64; following Pringle (footnote 53 above) at no. 56 and 97.

Margin no. 67.

Margin no. 66.

59 GFCC, OMT-judgment (footnote 47 above), margin no. 39: "It [the European Central Bank] is not authorised to pursue its own economic policy." See, also, margin no. 68: "The authority to support the general economic policies of the Member States at Union level (Art. 127 sec. 1 sentence 2 TFEU) does not justify any steering of economic policies in the System of European Central Banks.” 
consequences of their decisions for the general economic policy. The distinction and separation of tasks, powers, and competences have also played a major role in the ongoing debate on the "unconventional" measures taken by the Governing Council of the ECB fighting the financial crisis and its aftermath. However, the label "unconventional" might well prove only to be a euphemism for "illegal". 60

\subsubsection{The Fiscal Responsibility of the Member States}

In the language of the Union law, economic policy comprises also fiscal policy. This implies that the Union does not have - albeit with some explicit exceptions - the power to regulate the fiscal and budgetary decisions of the Member States. They have remained fully responsible for their fiscal policy and its results. Neither a (horizontal) federal equalisation system which is mainly intended to mitigate budgetary problems pro-actively has been established (1) nor an ex-post liability of the Union or Member States for the debt of each other (2). An open and much debated question has been the conformity of a purely voluntary financial assistance of Member States (3).

(1) Great care was taken by the framers of the Treaty of Maastricht that the Economic and Monetary Union did not include any trait of a horizontal or vertical (power) equalisation system among Member States or between the EU and the Member States. All Member States were expected to remain fully responsible for their finances, and no expectations were to be nourished that outside help would come in the event of budgetary problems. ${ }^{61}$ The capital markets were to provide the appropriate sanctions for unsound fiscal policy. Permanent instruments to prevent irresponsible fiscal policy were included in the legal framework besides the screening at admission time. Both safeguards, ${ }^{62}$ however, allegedly not fulfil their tasks properly. ${ }^{63}$

At EU level, it was envisioned that - in the absence of the possibility of depreciating a national currency after entering the third stage of the Monetary Union - the root causes of

60 See, for details, HeLmut SiEKMANn (2015), Section 3.3.

61 RenÉ Smits (1997), p. 77; Thomas MAYer (2010), p. 49; Helmut SieKMANN (2010).

62 On the safeguards to guarantee permanent stability of the EMU Section 1.3.4. above.

63 Jean-Victor Louis (2010), p. 979. 
economic and budgetary problems should be addressed by developing greater economic strength, which would eventually lead to the necessary convergence. This is also the reason for the existence of the structural funds and the cohesion fund of the EU which aim to improve the infrastructure of defined areas and/or to solve structural economic deficits. They have been greatly extended parallel to the introduction of the single currency ${ }^{64}$ and consume a large portion of all funds of the EU. ${ }^{65}$

These funds and programmes are now based upon Article 174 TFEU, which provides that, in order to strengthen its economic, social and territorial cohesion, the Union is to "aim at reducing disparities between the levels of development of the various regions and the backwardness of the least favoured regions" or islands, and that "particular attention is to be paid to rural areas, areas affected by industrial transition, and regions which suffer from severe and permanent natural or demographic handicaps”. A rich host of funds and programmes ${ }^{66}$ are now in operation ${ }^{67}$ to mitigate structural and regional imbalances at the roots:

- $\quad$ The European Regional Development Fund (ERDF); ${ }^{68}$

- $\quad$ The European Social Fund (ESF); ${ }^{69}$

Structural funds: Framework regulation 1993/2081, Official Journal of 31 July 1993, L 193/5; Coordination regulation 1993/2082, Official Journal of 31 July 1993, L 193/20; ERDF regulation 1993/2083, Official Journal of 31 July 1993, L 193/34; ESF regulation 1993/2084, Official Journal of 31 July 1993, L 193/39; EAGGF, Guidance Section regulation 1993/2085, Official Journal of 31 July 1993, L 193/44; FIFG regulation 1993/2080, Official Journal of 31 July 1993, L 193/1; Cohesion Fund: Regulation establishing the Cohesion Fund, 1994/1164, Official Journal of 25 May 1994, L 130/1; Regulation establishing a financial Cohesion Instrument.

HeRMANN-Josef BlANKE (2012), p. 107 provides 35 per cent as number.

66 Common and general provisions regulation - CPR: Regulation (EU) No 1303/2013 of the European Parliament and of the Council of 17 December 2013 laying down common provisions on the European Regional Development Fund, the European Social Fund, the Cohesion Fund, the European Agricultural Fund for Rural Development and the European Maritime and Fisheries Fund and laying down general provisions on the European Regional Development Fund, the European Social Fund, the Cohesion Fund and the European Maritime and Fisheries Fund and repealing Council Regulation (EC) No 1083/2006, Official Journal of 20 December 2013, L 347/320.

67 Period of 2014-2020.

68 ERDF regulation: Regulation (EU) No 1301/2013 of the European Parliament and of the Council of 17 December 2013 on the European Regional Development Fund and on specific provisions concerning the investment for growth and jobs goal and repealing Regulation (EC) No 1080/2006, Official Journal of 20 December 2013, L 347/289.

69

ESF regulation: Regulation (EU) No 1304/2013 of the European Parliament and of the Council of 17 December 2013 on the European Social Fund and repealing Council Regulation (EC) No 1081/2006, 
- $\quad$ The European Agricultural Fund for Rural Development (EAFRD); ${ }^{70}$

- $\quad$ The European Maritime and Fisheries Fund (EMFF); ${ }^{71}$

- $\quad$ The Cohesion Fund; ${ }^{72}$

- $\quad$ The European Territorial Cooperation Goal (ETC); ${ }^{73}$

- $\quad$ The European Grouping of Territorial Cooperation (EGTC). ${ }^{74}$

A clear distinction, however, has been maintained from a (power) equalisation system, as the funds are earmarked for specific purposes, mainly investments, and are not granted at the general disposition of a government with the possibility of handing out "gifts" to its electorate. The crucial point is to improve the competitiveness of the Member States which are in need. To the displeasure of many national or regional politicians, the correct disposition of these financial means is strictly controlled by the EU (Article 325 TFEU on combatting fraud), in specific by the Court of Auditors, established pursuant Article 13(1) TEU and Articles 285-287. This is a major difference to funds granted by a (federal) equalisation system.

(2) Neither the Union nor the Member States are to be liable for the commitments of any level of government of a Member State including its agencies, public undertakings, or any other body governed by public law. But it is not only liability that is strictly forbidden by the

Official Journal of 20 December 2013, L 347/470.

70 EAFRD regulation: Regulation (EU) No 1305/2013 of the European Parliament and of the Council of 17 December 2013 on support for rural development by the European Agricultural Fund for Rural Development (EAFRD) and repealing Council Regulation (EC) No 1698/2005. Official Journal of 20 December 2013, L $347 / 487$.

71 EMFF regulation: Regulation (EU) No 508/2014 of the European Parliament and of the Council of 15 May 2014 on the European Maritime and Fisheries Fund and repealing Council Regulations (EC) No 2328/2003, (EC) No 861/2006, (EC) No 1198/2006 and (EC) No 791/2007 and Regulation (EU) No 1255/2011 of the European Parliament and of the Council, Official Journal of 20 May 2014, L 149/1.

72 Cohesion Fund regulation: Regulation (EU) No 1300/2013 of the European Parliament and of the Council of 17 December 2013 on the Cohesion Fund and repealing Council Regulation (EC) No 1084/2006, Official Journal of 20 December 2013, L 347281.

73 ETC regulation: Regulation (EU) No 1299/2013 of the European Parliament and of the Council of 17December 2013 on specific provisions for the support from the European Regional Development Fund to the European territorial cooperation goal, Official Journal of 20 December 2013, L 347/259.

74 EGTC regulation: Regulation (EU) No 1302/2013 of the European Parliament and of the Council of 17 December 2013 amending Regulation (EC) No 1082/2006 on a European grouping of territorial cooperation (EGTC) with regard to the clarification, simplification and improvement of the establishment and functioning of such groupings, Official Journal of 20 December 2013, L 347/303. 
primary law of the Union, it is also the assumption of such a liability, Article 125(1) TFEU. This clause is the complement of the freedom that the Member States enjoy in economic and fiscal matters.

Only under extraordinary circumstances - not due to decisions of the government of the state in difficulty - may (limited) financial support by the EU be granted. The provisions are laid down in Article 122(2) TFEU: "natural disasters" or "exceptional occurrences beyond its [the Member States'] control”. This clause constitutes in no way a claim for support but authorizes measures at the discretion of the Council. The establishment of the European Financial Stabilisation Mechanism (EFSM) in 2010 by the EU was explicitly based upon this clause, ${ }^{75}$ although it remains questionable whether its pre-requisites were fulfilled. ${ }^{76}$

(3) Aside from this specific clause, it is an open and not-easy-to-answer question as to whether voluntary financial assistance by Member States ${ }^{77}$ would be admissible. ${ }^{78}$ In this context, it was called into question whether the aid granted by the Member States was compatible with Article 125 TFEU and the fundamental requirement of fiscal selfresponsibility. $^{79}$

Voluntary financial assistance by Member States is not explicitly regulated by the primary law. The wording of Article 125(1) TFEU could be interpreted in the way of an interdiction. In addition, the (restrictive) provisions of Article 122(2) TFEU may be used as

75 Council Regulation (EU) No 407/2010 of 11 May 2010 establishing a European financial stabilisation mechanism, Official Journal of 12 May 2010 L 118/1, recital 1; for details see note 51 above.

76 Kurt FaßBender (2010), p. 800 et seq; WALter Frenz and Christian EhlenZ (2010), pp. 213-215, specifically criticising the foundation of the EFSM on Article 122(2) TFEU (p. 212 et seq); HANNO KUBE and EKKEHARD REIMER (2011), p. 1914; KAI HENTSCHELMANN (2011), pp. 295-300, 304; DORIS HATTENBERGER (2012), margin no. 6, 9, 12; HERMANN-JOSEF BLANKE (2012), p. 106; CHRISTIAN CALLIESS (2013), p. 99 et seq; MiCHAEL PotACs (2013), p. 137 et seq; not objecting: GFCC judgment on support for Greece, BVerfGE 129 124; comment by MiCHAEL ELICKER and VERIS-PASCAL HEINTZ (2014); justification also by: Alberto De Gregorio Merino (2012), p. 1634, as Member of the Legal Services of the Council of the European Union; Christoph HERrmann (2010), p. 416; IDEM (2012), pp. 807, 808; MARTIN NeTTESHEIM (2012), pp. 66-73. The ECJ differentiates explicitly between setting up a stability mechanism and the power to grant assistance upon the basis of Article 122(2) TFEU which may only be used to grant temporary assistance but may not be used as basis for setting up a permanent mechanism, ECJ Pringle (note 53 above) at no. 64, 65, 116. For more details, see note 89 below. See note 51 above.

78 For details, see HELMUT SIEKMANN (2013), p. 132-137.

79 Vestert Borger (2013), p. 120, emphasises an interpretation of Article 125 TFEU as "the basic agreement” in contrast to Article 143(2) and Article 122(2) TFEU as its exceptions. 
an argument against the legality of financial support outside its range. Finally, the existence of Article 143(1) TFEU which regulates voluntary support for Member States whose currency is not the euro (states "with a derogation”, ${ }^{80}$ ), is an indication that financial support should not, otherwise, be admissible. ${ }^{81}$ Both norms could, however, also be interpreted as being only an authorisation of the organs of the EU, ${ }^{82}$ which is, perhaps, restricted to be used as an ultima ratio only. ${ }^{83}$

The European Court of Justice also took a lenient view of Article 125 TFEU as a starting-point and concluded from the language of this clause, in comparison with the allegedly much stricter language in Article 123 TFEU, that "it is not intended to prohibit any financial assistance whatever to a Member State”. ${ }^{84}$ It stated, notwithstanding, two constraints:

2. “(...) the activation of financial assistance by means of a stability mechanism such as the ESM is not compatible with Article 125 TFEU unless it is indispensable for the safeguarding of the financial stability of the euro area as a whole and subject to strict conditions." ${ }^{85}$

3. “(...) Article 125 TFEU does not prohibit the granting of financial assistance by one or more Member States to a Member State which remains responsible for its commitments to its creditors provided that the conditions attached to such

${ }^{80}$ For more details regarding them, see section 1.2.3. above.

81 KuRT FAßBENDER (2010), p. 800: Article 125 TFEU interdicts any kind of support; WALTER FrENZ and Christian EhLENZ (2010), pp. 212 et seq; HANNO KuBE and EKKEHARD REIMERS (2010), p. 1914; MARTIN SEIDEL (2011), p. 241; DANIEL Thym (2011), p. 169; CHRISTOPH DEgENHART (2012), p. 161 with further references: incompatible with Article 125 TFEU; idem (2013), p. 96: interdiction to grant aid.

82 Not objecting voluntary support: GFCC judgment on support for Greece, BVerfGE 129 124: ALBERTO DE GREGORIO MERINO (2012) [member of the Legal Services, Council of the European Union], p. 1627, under the condition of budgetary adjustments; WERNER HEUN and ALEXANDER THIELE (2012), p. 979; in favour of granting loans as compatible JochEN WiELAND (2011), p. 341; in effect also RENÉ SMITS (1997), p. 77 only interdicting the assumption of liabilities which follows already from the explicit wording of the clause.

83 ULRICH HÄDE (2010), pp. 859-862.

84 ECJ Pringle (note 53 above) at no. 132; supporting explicitly the opinion of the court: CHRISTIAN CALLIESS (2013), pp. 99, 103; Martin Nettesheim (2013), p. 14 et seq; Michael Potacs (2013), pp. 134.141 et seq; WolfGang Weiß and MARKus HABERKAMm (2013), p. 97 et seq; questioning the ECJ's interpretation of Article 125: Vestert Borger (2013), p. 133 et seq; Ulrich Palm (2014), Article 136 TFEU, margin no. 45 et seq.

85 ECJ Pringle (note 53 above) at no. 136. 
assistance are such as to prompt that Member State to implement a sound budgetary policy.”,86

The logic of the basic principles of the Monetary Union speaks, in fact, against the admissibility of voluntary support by Member States or the Union, unless the pre-requisites of the exemptions - interpreted strictly - are fulfilled. A differing interpretation would substantially undermine the (intended) pressure for budgetary discipline. ${ }^{87}$

The problem of the admissibility of financial support by Member States has been resolved by inserting paragraph three into Article 136 TFEU. ${ }^{88}$ The European Court of Justice has acknowledged its conformity with EU law, ${ }^{89}$ and the German Federal Constitutional Court its conformity with German constitutional law. ${ }^{90}$ According to the interpretation preferred here, this new clause ${ }^{91}$ is not only a clarification ${ }^{92}$ but opens constitutively the door to the granting of financial aid ${ }^{93}$ under certain restrictive conditions, which had hitherto been closed. This is also the assumption of the German Federal

87

UUT SIEKMANN (2013), pp. 134-137; VESTERT BORGER (2013), pp. 134-137.

European Council Decision of 25 March 2011 amending Article 136 of the Treaty on the Functioning of the European Union with regard to a stability mechanism for Member States whose currency is the euro (2011/199/EU), Official Journal of 6 April 2011, L 91/1; entering into force on 1 May 2013, BGBl II [Federal Law Gazette II], p. 1047.

ECJ (note 53 above), at margin no. 1 and 2, after an contradicting evaluation by the Supreme Court of Ireland; supporting: CHRISTOPH HERRMANN (2012), p. 807 et seq; VESTERT BORGER (2013), p. 127; critical: CHRISTOPH DEgENHART (2012), p. 162; IDEM (2013), pp. 95-97; UlRICH PALM (2014), Article 136 TFEU, primarily margin no. 45-47; only in view of the reasoning of the court, MATTHIAS RUFFERT (2013), p. 258; MARTIN NETTESHEIM (2013), pp. 14-17.

90 GFCC, judgment of 18 March 2014 upon the basis of the oral hearing of 11 and 12 June 2013, cases: 2 BvR 2728/13, 2 BvR 2729/13, 2 BvR 2730/13, 2 BvR 2731/13, 2 BvE 13/13, available at: (www.bundesverfassungsgericht.de/entscheidungen/rs20140318_2bvr139012en.html (in English) [ESM final judgment], in specific margin no. 177 et seq.

91 The new paragraph reads as follows: "The Member States whose currency is the euro may establish a stability mechanism to be activated if indispensable to safeguard the stability of the euro area as a whole. The granting of any required financial assistance under the mechanism will be made subject to strict conditionality.”

92 The ECJ (note 53 above) assesses a wide range of financial aid as compatible with Article 125 TFEU but inconsistently examines the compatibility of the new Article 136(3) with the primary law (margin no. 131 et seq., 138-143); consenting DANIEL THYM (2013), p. 262. This argumentation is highly questionable from a methodological point of view as the new article is primary law and must not be judged by a norm of the same level. Primary law may be changed by primary law at the discretion of the competent organs and institutions as long as the competences and procedures are obeyed.

93 Granting loans may have been compatible with Article 125 TFEU without Article 136(3) TFEU, WERNER Heun and AlexANDer Thiele (2012), p. 979, with further references; also in favour of differentiation, VESTERT BORGER (2013), p. 125. 
Constitutional Court in its decision recognising the admissibility of the insertion although it nonetheless acknowledges that the amendment constitutes a fundamental re-shaping of the European Economic and Monetary Union. ${ }^{94}$

\subsection{THE RULES ON GOVERNMENT DEFICITS AND DEBT ${ }^{95}$}

\subsubsection{Primary Law}

Although the Member States negotiating the Treaty of Maastricht could not reach a consensus about giving up their fiscal and budgetary autonomy, they conceded to insert binding rules on government deficits and debt into the primary law. ${ }^{96}$ The material rules are, however, only vague, and the procedure to enforce them is complicated, extended over a long period of time, open for discretionary decisions, and without the necessary sanctions. As a general rule, Member States are to avoid “excessive” government deficits. ${ }^{97}$ The primary law uses "the sustainability of the government financial position" as the essential criterion for a sustainable convergence in the framework of the Economic and Monetary Union. ${ }^{98}$ Even if this clause belongs to the transitional provisions, it can nonetheless be used as a basis for the interpretation of the obligation to "avoid excessive government debts".

The EU Commission has to monitor the development of the budgetary situation and of the stock of debt of all the Member States. The aspired budgetary discipline in particular is to be judged following the so-called Maastricht Criteria, ${ }^{99}$ which have found almost

94 GFCC, ESM final judgment (note 90 above), at margin no. 180: “(...) constitute indeed a fundamental reshaping of the existing Economic and Monetary Union, because it detaches its concept, albeit to a limited extent, from the principle of independence of the national budgets which had characterised it before (cf. on this BVerfGE 129, $124<181$ and 182>; 132, $195<248>$, n. 128; cf. however ECJ, Judgment of 27 November 2012, Case C-370/12 - Pringle -, n. 73 et seq.)”; agreeing CHRISTIAN CALliESs (2013), p. 104; Matthias Ruffert (2013), p. 259; see, also, Christian CALliess (2011a), p. 279; HANNo KuBE (2012), p. 245.

The following draws from HeLmUT SiEKMANN (2012), section D V; id. (2013), pp. 126-129.

96 Now Article 126 TFEU and Protocol (No 12) on the excessive deficit procedure, Official Journal of 26 October 2010, C 326/279.

97 Article 126(1) TFEU. The United Kingdom watered this clause somewhat down as it promised only to "endeavor to avoid an excessive government deficit"; No 5 of Protocol (No 15) (note 22 above).

98 Article 140(1) indent 2 TFEU.

99 Not unfrequently, the criteria used to judge whether a Member State fulfils the necessary conditions to adopt the euro are also called "Maastricht Criteria"; see, for example, CHARLES PROCTOR (2012), margin no. 26.13 and 26.14. The naming of these four criteria, laid down in Article 140(1) TFEU and further developed in 
ubiquitous dissemination in political debate, economic analysis, and the media: (a) the ratio of government deficit to gross domestic product, and (b) the ratio of government debt and gross domestic product. ${ }^{100}$ The first reference value has been set at 3 per cent and the second at 60 per cent. ${ }^{101}$ These reference values are part of the primary law of the Union. ${ }^{102}$

A lot of confusion and, presumably, intentional mis-representation has to be observed with regard to these rules. This holds especially in view of alleged "breaches" of the Stability and Growth Pact and alleged "transgressions" of the "Maastricht” limits for government deficits and debt. This is why the following should be absolutely clear: (1) the described rules are not the Stability and Growth Pact even though this is almost permanently claimed in public; (2) the numeric values of the ratios (3 per cent and 60 per cent) are not binding limits. They serve only as reference values in a complex assessment procedure with plenty of additional vague terminology and a notable amount of discretionary power vested in the competent organs of the EU. The only certain and strict obligation lacking any discretionary power is, that, in the event that the Commission has come to the conclusion that an excessive deficit exists, ${ }^{103}$ the Council may not simply stop the procedure and do nothing, as it had decided in respect of the unsound deficits of Germany and France in $2003 .{ }^{104}$

The Excessive Deficit Procedure (EDP) may result in admonitions and recommendations. ${ }^{105}$ If a Member State persistently fails to implement the recommendations, sanctions may be imposed which may eventually entail a non-interest-bearing deposit with the Union or a "fine of an appropriate size". ${ }^{106}$ In essence, both the procedural and the substantial rules for enforcing the requirement of permanent budgetary discipline are laid

Protocol (No 13) on the convergence criteria (Official Journal of 26 October 2012, C 326/281), should, however, follow the terminology of the primary law. They are to be called "convergence criteria". This also helps to avoid confusion.

100 Article 126(2) TFEU.

101 Article 1 Protocol (No 12) (note 96 above).

102 Article 51 TEU.

103 Following Article 126(6) TFEU.

${ }^{104}$ ECJ, judgment of 13 July 2004 - C-27/04 (Commission vs. Council), Europäische Zeitschrift für Wirtschaftsrecht, 2004, p. 465; Juristen Zeitung, 2004, p. 1069 with comment, MARKUS KoTZUR; see, also, Dimitrios Doukas (2005); BARbara Dutzler and ANGElika HABle (2004); GerT NiCOlaysen (2004), p. 1322, 1325; CHRISTOPH DEGENHART (2012), p. 161.

105 Article 126(7-9) TFEU.

106 Article 126(11) sub-paragraph 1. 
down in the primary law of the Union. However, really effective sanctions have not been embodied. Specifically, an exclusion of a Member State from the eurozone is not foreseen and would be illegal. ${ }^{107}$

From its inception, it has been criticised that the procedure provided in the primary law would be too tedious and, above all, that the political determination would be lacking to impose appropriate sanctions. ${ }^{108}$ The definitions and specifications of the rules on both government debt and deficits and the deficit procedure had been undertaken by the secondary law of the Union, but no reduction of the scope of discretion for imposing sanctions was provided. ${ }^{109}$ It was mainly Germany that demanded a "stability pact", preferably with automatic sanctions. $^{110}$

\subsubsection{Secondary law}

\section{The Stability and Growth Pact}

The Stability and Growth Pact is neither an agreement nor a treaty, but three acts of secondary law. ${ }^{111}$ The term "pact" was retained to emphasise the underlying political consensus. $^{112}$ It can be taken as a remnant of the initially considered separate treaty. Technically, the pact consists of one resolution of the European Council, ${ }^{113}$ which is legally

107 PAUl KiRCHHOF (1994), p. 72; probably also CHRISTOPH HERRMANN (2010b), p. 417; for more details, see Section 4.3. below.

108 FRANZ-CHRISTOPH ZEITLER (1995), p. 1611.

109 Council Regulation (EC) No 3605/93 of 22 November 1993 on the application of the Protocol on the excessive deficit procedure annexed to the Treaty establishing the European Community, Official Journal of 31 December 1993, L 332/7; amended several times, codified version: Council Regulation (EC) No 479/93 of 25 May 2009, on the application of the Protocol on the excessive deficit procedure annexed to the Treaty establishing the European Community, Official Journal of 10 June 2009, L 145/1; Council Regulation (EC) No 3603/93 of 13 December 1993 specifying definitions for the application of the prohibitions referred to in Articles 104 and 104b(1) of the Treaty, Official Journal of 31 December 1993, L 332/1.

110 A “Stabilitätspakt für Europa” was presented by the German Minister of Finance on 10 November 1995; see for details, UlRiCh PALM (2000), pp. 44 et seq., 142; UlRICH HÄDE (1996), p. 139; extensively on this and the origins of the Stability and Growth Pact, KAI HentsCHELMANN (2009), pp. 205-285.

111 For the following, see, already, HELMUT SiEKMANN (2012), Section D V 2.

112 Explicitly expressed in recital no. 2 of both regulations, notes 115 and 116 below.

113 Resolution of the European Council on the Stability and Growth Pact Amsterdam of 17 June 1997, Official Journal of 2 August 1997, C 236/1. 
not binding, ${ }^{114}$ and two - binding - regulations. One is mainly designed as an early warning system and is called preventive arm of the "pact". ${ }^{115}$ The other contains mainly procedural rules in the event that a Member State shows a lack of budgetary discipline, and is called the corrective arm of the "pact". 116 The resolution contains a multilateral promise to achieve an almost balanced budget in the medium term. As the corrective arm is based upon Article 126(14) sub-paragraph 2 TFEU empowering the Council to enact rules which replace the Deficit Protocol (No 12), the extent to which this may be done is/remains an open and much debated question. $^{117}$

The Stability and Growth Pact sets as its goal a "close to balance or in surplus position” of the budget. This is an enhancement compared to the requirement of Article 126(1) TFEU which was to “avoid excessive government deficits”.

\section{Revisions of the Stability and Growth Pact - An Overview}

The requirements of the Stability and Growth Pact can be relaxed much easier and faster than primary law since they are no treaties - counterfactual to their labelling - which can be amended only unanimously. Such a relaxation was readily done in $2005,{ }^{118}$ ironically at the special request of the German government. ${ }^{119}$

With the evolvement of the financial crisis into a sovereign debt crisis in Europe, the legal instruments of the Stability and Growth Pact were enhanced and tightened in several

114 But allegedly a "political” obligation, see HUGO J. HAHN and ULRICH HÄDE (2010), p. 318 with further references for varying opinions.

${ }^{115}$ Council Regulation (EC) No 1466/97 of 7 July 1997 on the strengthening of the surveillance of budgetary positions and the surveillance and coordination of economic policies, Official Journal of 2 August 1997, L 209/1.

116 Council Regulation (EC) No 1467/97 of 7 July 1997 on speeding up and clarifying the implementation of the excessive deficit procedure, Official Journal of 2 August 1997, L 209/6.

For details, see ChARLOTTE GAITANides (2013), Article 126 TFEU margin no. 162 et seq.

118 Council Regulation (EC) No 1055/2005 amending Regulation (EC) No 1466/97 on the strengthening of the surveillance of budgetary positions and the surveillance and coordination of economic policies of 27 June 2005, Official Journal of 7 July 2005, L 174/1; Council Regulation (EC) No 1056/2005 amending Regulation (EC) No 1467/97 on speeding up and clarifying the implementation of the excessive deficit procedure of 27 June 2005, Official Journal of 7 July 2005, L 174/5.

119 Critical namely: Deutsche Bundesbank (2005a), p. 42; Deutsche Bundesbank (2005b), p. 21; also European Central Bank (2011a), p. 113 with reference to European Central Bank (2005), where the criticism is indirect and rather mild; for more details, see CHARLOTTE GAITANIDES (2013), margin no. 23 et seq. 
steps: first, by the so-called "six-pack" legislation in 2011 which not only contained amendments of the Stability and Growth Pact, ${ }^{120}$ but also rules on the prevention and mitigation of macro-economic imbalances, ${ }^{121}$ and on budgetary surveillance; ${ }^{122}$ not only for the euro area but also for the whole EU, including the "Member States with a derogation”. ${ }^{123}$ As these reforms left considerable room for continuing scepticism, ${ }^{124}$ a second round of enhancements was adopted in 2013, the so-called "two-pack". ${ }^{125}$

It was a major goal of the reforms to make the Excessive Deficit Procedure (EDP) more effective:

${ }^{120}$ Regulation No 1175/2011 of the European Parliament and of the Council of 16 November 2011 amending Council Regulation (EC) No 1466/97 on the strengthening of the surveillance of budgetary positions and the surveillance and coordination of economic policies, Official Journal of 23 November 2011, L 306/12 (strengthens the preventive surveillance and coordination instruments of the Stability and Growth Pact); Regulation No 1177/2011 of the European Parliament and of the Council of 8 November 2011 amending Regulation (EC) No 1467/97 on speeding up and clarifying the implementation of the excessive deficit procedure, Official Journal of 23 November 2011, L 306/33 (aims to improve the effectiveness of the corrective measures in case of an excessive deficit by providing stricter requirements for the stages of the deficit procedure pursuant to Art. 126 TFEU).

${ }^{121}$ Regulation (EU) No 1174/2011 of the European Parliament and of the Council of 16 November 2011 on enforcement measures to correct excessive macroeconomic imbalances in the euro area, Official Journal of 23 November, L 306/8 (provides a system of sanctions for the effective correction of excessive macroeconomic imbalances in the euro area [Art. 1]).

Regulation (EU) No 1176/2011 of the European Parliament and of the Council of 16 November 2011 on the prevention and correction of macroeconomic imbalances, Official Journal of 23 November 2011, L 306/25 (sets out detailed rules for the detection of macroeconomic imbalances, as well as the prevention and correction of excessive macroeconomic imbalances within the Union [Art. 1 sec. 1]).

122 Regulation (EU) No 1173/2011 of the European Parliament and of the Council of 16 November 2011, on the effective enforcement of budgetary surveillance in the euro area, Official Journal of 23 November 2011, L 306/1 (sets out a system of sanctions for enhancing the enforcement of the preventive and corrective parts of the Stability and Growth Pact in the euro area [Art. 1]).

Council Directive 2011/85/EU of 8 November 2011 on requirements for budgetary frameworks of Member States, Official Journal of 23 November 2011, 2011/L 306/41 (aims to ensure transparency and availability of the necessary data, which are a requirement for compliance with and enforcement of the obligations under the Treaties regarding the avoidance of excessive budgetary deficits, with detailed requirements for, inter alia, public accounting systems, the use of numerical fiscal rules, medium-term budgetary forecasts and the implementation of independent analysis and monitoring).

${ }^{123}$ For more details on them, see Section 1.2.3. above.

124 Critical in-depth assessment by ScHUKNECHT/MOUTOT/RothER/STARK (2011); fo details see HERMANNJOSEF BLANKE (2012), pp. 83-95, judging the measures as not going far enough (p. 94).

125 Regulation (EU) No 472/2013 of the European Parliament and of the Council of 21 May 2013 on the strengthening of economic and budgetary surveillance of Member States in the euro area experiencing or threatened with serious difficulties with respect to their financial stability, Official Journal of 27 May 2013, L 140/1; Regulation (EU) No 473/2013 of the European Parliament and of the Council of 21 May 2013 on common provisions for monitoring and assessing draft budgetary plans and ensuring the correction of excessive deficit of the Member States in the euro area, Official Journal of 27 May 2013, L 140/11; critical assessment: European Central Bank (2013). 
"Overall, the two main objectives of the six-pack and two-pack reforms in the area of fiscal surveillance were (1) a strengthened and deepened budgetary surveillance by making it more continuous and integrated, also via an intensified sanctions mechanism; and (2) an additional surveillance for euro area Member States to ensure the correction of excessive deficits and an appropriate integration of EU policy recommendations in the national budgetary preparation."

For the Member States of the euro area a semi-automatic sanctioning mechanism was introduced in the framework of the preventive arm. It is designed to work via a reversed voting mechanism. $^{127}$

\section{The Preventive Arm}

The preventive arm aims to ensure the underlying strength of the Member States' public finances in order to create macroeconomic stability and the fiscal space to address the economic shocks that may arise. The core requirement is that Member States reach and maintain a Medium Term Objective (MTO), a country-specific budgetary reference value defined in structural terms (that is, cyclically adjusted and net of one-off and temporary measures). The country specific MTO is to be set within a safety margin in view of the 3 per cent deficit limit, ensure rapid progress towards sustainability, and allow room for budgetary manoeuvre. For the euro area and the exchange rate mechanism (ERM II) Member States, the limit has to be set at -1 per cent of GDP. The 2011 reform introduced an expenditure benchmark: the expenditure net of discretionary measures should grow less than the mediumterm potential GDP. ${ }^{128}$

The preventive arm requires that the Member States of the euro area transmit yearly a "stability programme" to the Commission in order to facilitate surveillance. "The Member States with a derogation” transmit “convergence programmes”. A major component of both

\footnotetext{
${ }^{126}$ Communication from the Commission to the European Parliament, the Council, the European Central Bank, the European Economic and Social Committee and the Committee of the Regions, Economic governance review, Report on the application of Regulations (EU) no 1173/2011, 1174/2011, 1175/2011, 1176/2011, 1177/2011, 472/2013 and 473/2013, 28. November 2014, COM(2014) 905 final, p. 4.

${ }^{127}$ Article 4 regulation 1173/2011 (supra footnote 122); for details, see CHARLOTTE GAITANIDES (2013), margin no. 45 et seq.

${ }^{128}$ EuROPEAN COMmission (2014a), Annex 1.
} 
programmes is the formulation of an adjustment path towards meeting the benchmarks. The adjustment path towards a sustainable deficit has 0.5 per cent of GDP as its benchmark and should follow the general rule: more in good times, less in bad times. The 2011 reform tightens the adjustment requirement and introduced the obligation to reduce the deficit by more than 0.5 per cent of GDP under two conditions: (i) the debt level is greater than 60 per cent of GDP; or (ii) “pronounced sustainability risks” exist. ${ }^{129}$

A temporary deviation from the adjustment path is allowed if the implementation of major structural reforms with a verifiable impact on the long-term sustainability of public finances - emphasis on pension reform - is undertaken. The 2011 revision also allowed deviations in the event of: (i) an unusual event outside the control of the Member State concerned with a major impact on its financial position; and (ii) a severe economic downturn for the euro area or the EU as a whole provided this does not endanger the medium-term fiscal sustainability. ${ }^{130}$

The enforcement of these rules was significantly enhanced by the 2011 revision: A procedure for correcting significant deviations (0.5 per cent in one year or cumulatively over 2 years from the MTO or the adjustment path) was installed. For euro area Member States, financial sanctions (interest-bearing deposit of up to 0.2 per cent of GDP) in the event of repeated non-compliance are foreseen.

\section{The Corrective Arm}

The objective of the corrective arm of the Stability and Growth Pact is the correction of gross policy errors. The 2011 revision laid increased emphasis on the debt criterion and aims at speeding up the convergence to sustainable debt limits. As a starting-point, the 3 per cent of GDP deficit and the 60 per cent of GDP debt or a "sufficiently diminishing debt" remain as the thresholds. The reform specified numerically what has to be considered as "sufficiently diminishing”. A debt will now be considered as sufficiently diminishing if the debt reduction benchmark is respected. The debt reduction benchmark is set at a reduction of 5 per cent per year on an average over 3 years (one-twentieth of the gap to 60 per cent) taking the cycle into

\footnotetext{
129 IBID.

130 IBID.
} 
account, or, if the benchmark is respected, in the next two years regardless of the cycle. A minimum annual improvement of the deficit of 0.5 per cent of GDP is required as a benchmark in structural terms. ${ }^{131}$

\section{Specific Amendments by the "Two-pack” Regulations}

The first regulation of the "two-pack" ${ }^{132}$ codifies a regime of "enhanced surveillance" for a Member State which is in one of the following situations: (i) experiencing serious difficulties with regard to its financial stability or is threatened by them without receiving financial assistance; or (ii) receiving financial assistance on a precautionary basis, for instance, from the European Financial Stability Facility, the European Stability Mechanism, or the International Monetary Fund (IMF). Under certain conditions, the Commission, in liaison with the ECB and - where applicable - the IMF, must conduct "regular review missions" in order to ascertain that the envisaged "progress in implementing the agreed measures" is made. In a further step, a "macroeconomic adjustment programme” may replace the EDP targets in the event that financial assistance is requested. ${ }^{133}$

The second regulation of the "two-pack" ${ }^{134}$ requires Member States to publish their medium-term fiscal plans by 30 April each year and the draft of their annual budgets by 15 October. The budget is to be adopted by 31 December at the latest. In the event of "particularly serious non-compliance" with the budgetary policy obligation, the Commission will have to "adopt an opinion on the draft budgetary plan" and request "revised draft budgetary plans”. 135

\section{Effectiveness of the Reforms}

In its economic governance review of November 2014, the EU-Commission reviewed the effectiveness of the "six-pack" (2011) and the "two-pack" (2013). Although expressly

\footnotetext{
131 IBID., p. 3 and footnote 4.

132 Regulation 472/2013 (note 125 above).

133 EUROPEAN CENTRAL BANK (2013), p. 54.

134 Regulation 473/2013 (note 125 above).

135 EUROPEAN CENTRAL BANK (2013), p. 53.
} 
acknowledging the short time-span since their adoption, it arrived at the overall assessment that the "reformed framework has proven effective in strengthening budgetary surveillance and thus in guiding Member States in their efforts to consolidate public finances in difficult economic conditions". The Commission admits, however, that the "specific contribution" of the new rules is "difficult to distinguish from other factors", and that "first experience suggests that the reformed fiscal rules indeed have played a role”. ${ }^{136}$ In the light of the most recent handling of the rules with regard to the budgetary plans of France doubts ramain whether the Commission has the necessary verve to enforce the rules in view of a big Member State.

\subsubsection{Euro Plus Pact}

The so-called Euro Plus Pact is neither a legislative act of the EU, nor a treaty. It is a declaration adopted by the European Council, ${ }^{137}$ even though the German Federal Constitutional Court calls it a treaty:

"Pursuant to the text of the treaty and its conclusions, it aims to strengthen the economic pillar of the monetary union, to achieve a new quality of economic policy coordination between the Member States of the euro currency area, to improve their competitiveness, and thereby to achieve a higher degree of convergence. The focus is to be placed primarily on the policy areas that fall within the competences of the Member States and which are crucial for increasing competitiveness and avoiding harmful imbalances." ${ }^{138}$

In fact, it appears more to be a camouflage in order to allow additional spending programmes which might be questionable with regard to the provisions of the Stability and Growth Pact.

\footnotetext{
136 EUROPEAN COMMission (2014a), p. 5. Detailed and disaggregated numbers within the context of fiscal surveillance can be found in the 2014 report on public finances of the European Commission (2014b), especially in Part III.

137 EUCO 10/1/11 REV 1, Annex I.

${ }^{138}$ GFCC ESM final judgment (note 90 above), margin no. 18; see, for details, BVerfGE 131, 152 et seq.
} 


\subsubsection{Law of Nations}

The regulations of the "Stability and Growth Pact" and its foundations in the primary law were supplemented by new contractual arrangements among the Member States for more fiscal stability in the eurozone. They have to be considered as part of the law of nations, in contrast to EU law.

By joining the European Union, a Member State does not lose its capacity to close treaties governed by the law of nations, even in fields which principally fall within the domain of the European Union. This is also true for treaties among a subset of Member States of the EU, such as those whose currency is the euro. However, some caveats have to be respected:

- Treaties of this kind may only deal with topics which are covered by Member State competences. This implies that they may never regulate a matter which falls within the exclusive competences ${ }^{139}$ of the EU, such as the monetary policy for the Member States whose currency is the euro, Article 3(1)(c) TFEU; and

- The provisions of such a treaty must be compatible with “common legal rules” of the EU. ${ }^{140}$

As has already been stated, general economic policy - including fiscal policy - does not belong to the competences of the EU. In principle, it has remained with the Member States. This was the intention of the framers of the Economic and Monetary Union. ${ }^{141}$ Fiscal and budgetary policies are part of the (general) economic policy, ${ }^{142}$ with the exception of the provision on government deficit and debt in Article 126 TFEU.

Exercising this (residual) power, on 2 March 2012, the heads of state or government of 25 Member States ${ }^{143}$ signed the "Treaty on Stability, Coordination and Governance in the

\footnotetext{
${ }^{139}$ More details Section 1.2.1. above.

140 ECJ, Case C-524/04, Test Claimants, reports 2007, I-2107 margin no. 49, 53; ECJ Pringle (supra footnote 53) at no. 68, 98, 101; KoEn LeNAERTS and Piet VAN Nuffel (2011), margin no 22-110; Christian TiETJE (2011), p. 10 et seq; RudOLF STREINZ (2012b), margin no 524, 526 specifically for the fiscal treaty.

${ }^{141}$ Section 1.1. above.

142 Section 1.4.1.above.

143 As the United Kingdom and the Czech Republic objected an amendment of the primary law the way of a
} 
Economic and Monetary Union", which became better known as the (new) "fiscal compact”. ${ }^{144}$ It entered into force on 1 January $2013^{145}$ after ratification by twelve member states of the euro area. ${ }^{146}$

The Treaty introduced strengthened rules for fiscal discipline and stricter surveillance within the euro area without prejudice to the legal obligations from the EU-law, ${ }^{147}$ in particular, by establishing a "balanced budget rule". According to the provisions of the Treaty, "national budgets must be in balance or in surplus under the balanced budget rule, a criterion that is met if the annual structural government deficit does not exceed 0.5 per cent of GDP at market prices. ${ }^{148}$ They must also be in line with the country-specific medium-term budgetary objective, as defined in the EU's stability and growth pact.

The balanced budget rule has to be incorporated into the Member States' national legal systems, preferably at constitutional level, within one year of the entry into force of the Treaty, i.e., by 1 January 2014. ${ }^{149}$ In the event of deviation from the balanced budget rule, an automatic correction mechanism is triggered. It will be defined by each Member State upon the basis of principles proposed by the European Commission and endorsed by the signatories. The violation of these rules may result in fines up to 0.1 per cent of the GDP of the Member State in question. The implementation in national law can be enforced by legal action in the European Court of Justice (ECJ). ${ }^{150}$

separate treaty or compact had to be chosen, FRANK SCHORKOPF (2012), p.3, 14, 17.

144 Adopted and transformed into German law by act of 13 September 2012, BGBl II [Federal Law Gazette II] 2012, p. 1006, giving the text of the treaty also in English.

145 BGBl II [Federal Law Gazette II] 2013, p. 162. The Act on the National Implementation of the Fiscal Compact entered into force on 19 July 2013, BGBl I [Federal Law Gazette I] 2013, p. 2398.

146 Austria, Cyprus, Germany, Denmark, Estonia, Spain, France, Greece, Italy, Ireland, Lithuania, Latvia, Portugal, Romania, Finland, and Slovenia. Finland deposited its instrument of ratification 21 December 2012.

147 FRANK SCHORKOPF (2012), p. 6, 14.

148 This is a contractual obligation: DoRIS HATTENBERGER (2012), Article 126 TFEU margin no 70; RÜDIGER BANDILLA (2012), Article 126 TFEU margin no 120.

149 Article 3(2) sentence 1 fiscal compact; see, also, press release of the EU-Commission, 21 December 2012, 18019/12, PRESSE 551.

${ }^{150}$ For more details, see: FrAnK SCHORKOPF (2012); HeRMANN-JoseF Blanke (2012); ChARLOTTE GAITANIDES (2013), margin no. 169-190. 


\section{THE EUROPEAN SYSTEM OF CENTRAL BANKS}

\subsection{THE ESCB AS THE CORE CONTENT OF THE MONETARY UNiON}

The European Central Bank (ECB) together with the national central banks of all Member States form the European System of Central Banks (ESCB). ${ }^{151}$ It is construed as a decentralised but single entity of the European Union (EU) and resembles the Federal Reserve System of the United States in this aspect. The ESCB is the core content of the Monetary Union, which, in its turn, forms an integral part of the EU (Part Three, Title VIII TFEU). An often forgotten trait is that the central banks of all the Member States including those "with a derogation”, ${ }^{152}$ and not just those whose currency is the euro, are part of the ESCB.

\subsection{THE INSTITUTIONAL SET-UP OF THE ESCB}

\subsubsection{The ESCB}

The ESCB is governed by the decision-making bodies of the ECB: the Governing Council, the Executive Board, and the General Council. ${ }^{153}$ The ESCB does not have legal personality.

The monetary authority transferred to the Union does, in fact, not only comprise the competence and power to employ the usual instruments that central banks command to regulate interest rates and the volume of money, but also the regulation of foreign exchange rates and international agreements on money and monetary policy. The latter, however, do not belong to the competences passed on to the ESCB, ${ }^{154}$ although it is stated indiscriminately in Article 282(1) sentence 2 TFEU that the European Central Bank, together with the national central banks of the Member States whose currency is the euro, is to conduct the "monetary policy of the Union". Article 219 TFEU dealing with the fixing of foreign exchange rates by the Council shows that the term "monetary policy" is used with different meanings depending on the context.

\footnotetext{
151 Article 282(1) sentence 2 TFEU.

${ }^{152}$ For details, see p. 7 above.

153 Article 282(2) sentence 1 TFEU.

154 GERT NiCOLAYSEN (1993), p. 29.
} 


\subsubsection{The Eurosystem}

The European Central Bank together with the national central banks of the Member States whose currency is the euro constitute the Eurosystem, Article 282(1) sentence 2 TFEU.

\subsubsection{The ECB}

In contrast to the ESCB, the ECB has legal personality, Article 282(3) sentence 1 TFEU. Its decision-making bodies are the Governing Council and the Executive Board, Article 283(2) TFEU with 6 members.

The Executive Board comprises the President, the Vice-President and four other members, making 6 members in total, Article 283(1) sub-paragraph 1 TFEU. They have to be nationals of the Member States and are appointed by the European Council, acting by a qualified-majority, “from among persons of recognised standing and professional experience in monetary and banking matters”, Article 283(1) sub-paragraphs 2 and 4 TFEU. Their term of office is a fixed period of eight years and is not renewable, Article 283(1) sub-paragraph 3 TFEU.

The Governing Council comprises the members of the Executive Board of the ECB and the Governors of the national central banks of the Member States whose currency is the euro. Since Latvia introduced the euro on 1 January 2015, it has 25 members.

For monetary policy decisions, the primary law follows the principle of "one member, one vote”, Article 10.2. sentence 1 Statute EXCB/ECB. However, from the date on which the number of members of the Governing Council exceeds 21, only 15 governors from the national central banks will have the right to vote following a complicated rotation system, outlined in the remainder of Article 10.2. Statute EXCB/ECB. This restriction may be necessary for practical purposes, but may lead to the exclusion of voices from major participating countries.

\subsubsection{The ECB and National Central Banks}

The national central banks are an integral part of the ESCB. They are to act in accordance with guidelines and instructions of ECB, Article 14.3. Statute ESCB/ECB. Additional 
functions may be performed by the national central banks unless a two-third majority of the Governing Council deems that they are interferring with the objectives and tasks of the ESCB, Article 14.4. Statute ESCB/ECB. A special procedure at the European Court of Justice has been implemented to enforce the obligations of the national central banks, Article 35.6. Statute ESCB/ECB.

\subsubsection{The Finances of the ECB}

The national central banks, not the Member States, are the sole subscribers and holders of the capital of the ECB, Article 28.2. Statute ESCB/ECB. No minimum capital is required. Both ECB and national central banks may even have negative capital. Only a limited liability of the national central banks for losses has been stated, Article 33.2. Statute ESCB/ECB. Any attempt to establish further contributions, levies, or taxes to finance losses of the ECB would not be consistent with the primary law of the EU.

\subsection{THE COMPREHENSIVE GUARANTEE OF INDEPENDENCE}

The primary law provides for a comprehensive guarantee of the independence of the European Central Bank, the national central banks, and all members of their decision-making bodies, Articles 130, 131, 282(3) sentence 2 TFEU. Several aspects of independence can be distinguished:

- institutional;

- personal; and

- financial. $^{155}$

The personal independence of the members of the Executive Board is warranted by several provisions: the fixed term of office with no possibility of renewal and the removal from office only under very restrictive conditions.

155 For an in-depth analysis of the independence guarantee, see BARBARA DUTZLER (2003), p. 88-109; Charlotte GaitAnides (2005), p. 199-279; WERnER Heun (1998), p. 874 et seq; Helmut SieKMANN (2013), Article 130 TFEU. 
Only if a Board Member no longer fulfils the conditions required for the performance of his or her duties or if he or she has been found guilty of serious misconduct, removal from office is foreseen by the EU primary law. If these conditions are met, (compulsory) retirement has to ensue. But it is neither the appointing institution, nor an organ of the ECB, that has the power to take such a measure. It is reserved to the independent judiciary. The European Court Justice has to retire the member in question, Article 11.4. Statute ESCB/ECB.

The primary law does not protect the personal independence of the Members of the Governing Council to the same degree as it does in view the Executive Board. It only prescribes a minimum term of office of five years for the Governors of national central banks and contains no interdiction of the renewal of their term of office, Article 14.2. Statute ESCB/ECB. Experience tells that a long duration of office combined with the lack of the possibility of renewal are the strongest safeguards for true independence. The desire for renewal of the terms of office may de facto pose a significant threat for independent and unbiased decisions.

\subsection{LIMITED TASKS}

The primary law lists, in Article 127(2) TFEU, basic tasks of the ESCB as:

- $\quad$ the defining and implementing of the monetary policy of the Union;

- the conducting of foreign-exchange operations with prejudice to Article 219 TFEU;

- the holding and managing of foreign reserves; and

- the promoting of the smooth operation of payment systems.

For monetary policy, a restatement can be found in Article 282(1) sentence 2 TFEU: the "European Central Bank, together with the national central banks of the Member States whose currency is the euro, (...), shall conduct the monetary policy of the Union.” Thus, it is effectively the Eurosystem which has to conduct the monetary policy of the Union. 
Not a basic task of the ESCB are the following:

- $\quad$ general economic policy; ${ }^{156}$

- the stability of the financial system; and

- the supervision of the financial institutions.

The ESCB shall "contribute to the smooth conduct of policies pursued by the competent authorities relating to the prudential supervision of credit institutions and the stability of the financial system", Article 127(5) TFEU. As it shall only "contribute” to the policies of the "competent" authorities, it does not have a competence of its own for these tasks.

When framing the Monetary Union, it was a fiercely debated topic whether the new European Central Bank should have competences in banking supervision. ${ }^{157}$ It was finally agreed that banking supervision should not belong to its tasks, in contrast to the first draft of the statutes by the committee of central bank governors. ${ }^{158}$ Already in the final draft, it was reduced to an advisory function. ${ }^{159}$ The actual wording of the norm states that the ECB is only to play an ancillary role by "contributing” to supervision by other authorities and has no powers of its own in this field. However, consensus could be reached to the effect that a limited transfer of competences should not be blocked in the future should it become a common wish of the Member States. Thus, Article 127(6) TFEU from the beginning allowed for "specific tasks (...) concerning policies relating to the prudential supervision of credit institutions and other financial institutions with the exception of insurance undertakings” may be conferred upon the ECB by unanimous vote of the Council. This means that the conferral requires the consent of all Member States. In the meantime, a conferral has been adopted within the framework of the so-called Banking Union (the Single Supervisory Mechanism SSM). ${ }^{160}$

\footnotetext{
${ }^{156}$ Section 1.4. above.

157 Harold JAmes (2012), p. 313; see, also, Christos HADJIEMMANUIL (1996).

158 STEFAN GlatZl (2009), p. 257; HAROLD JAMES (2012), pp. 292, 315.

159 RENÉ SMITS (1997), pp. 335-337.

160 Council Regulation (EU) No 1024/103 of 15 October 2013 conferring specific tasks on the European Central Bank concerning policies relating to the prudential supervision of credit institutions, Official Journal of 29 October 2013, L 287/63; Regulation (EU) No 1022/2013 of the European Parliament and of the Council of
} 


\section{THE EURO}

\subsection{MEMBER STATES WHOSE CURRENCY IS THE EURO}

As already mentioned, ${ }^{161}$ all Member States are obliged to introduce the euro unless an exemption has been granted by primary law. In effect, 19 of the 28 Member States have introduced the euro by now. The initial participating countries were Austria, Belgium, Finland, France, Germany, Ireland, Italy, Luxembourg, the Netherlands, Portugal, and Spain. ${ }^{162}$ Greece was admitted before the introduction of euro notes and coins on 1 January 2002. ${ }^{163}$ Cyprus, Malta, Slovenia, Slovakia, and Estonia followed. The last country to be admitted was Lithuania. The United Kingdom and Denmark did not adopt the euro in accordance with the exemptions granted to them. ${ }^{164}$ Sweden refrained from continuing the process of introducing the euro, ${ }^{165}$ although it would - on closer scrutiny - have fulfilled all the admittance requirements.

As a result, the following Member States of the EU have not introduced the single European currency to date: Bulgaria, Croatia, the Czech Republic, Denmark, Hungary,

22 October 2013 amending Regulation (EU) No 1093/2010 establishing a European Supervisory Authority (European Banking Authority) as regards the conferral of specific tasks on the European Central Bank pursuant to Council Regulation (EU) No 1024/2013; for more details, see AlEXANDER ThIELE (2014b), pp. 521-523.

161

Section 1.2.2. above.

162 Regulation (EC) No 974/98 of the Council, 3/5/1998, Official Journal of 11 May 1998, L 139/1.

163 Council decision (2000/427/EC) of 19 June 2000 in accordance with Article 122(2) of the Treaty on the adoption by Greece of the single currency on 1 January 2001, Official Journal of the European Communities of 7 July 2000 L 167/19; Council Regulation (EC) No 2169/2005 of 21 December 2005 amending Regulation (EC) No 974/98 on the introduction of the euro, Official Journal of 29 December 2005 L 346/1; for the legislative history cf. EU Bulletin 5 - 2000, point 1.3.5: 3 May 2000 "the Commission adopts a proposal for a Council decision aiming the adoption by Greece of the single currency on 1 January 2001. On the basis of the report of the European Central Bank (adopted on 27 April 2000) and of its own 2000 convergence report, the Commission has concluded that Greece fulfils the necessary conditions for the adoption of the single currency and is proposing a Council decision abrogating Greece's derogation from its obligations regarding the achievement of economic and monetary union. The derogation would be abrogated with effect from 1 January 2001. The report (document COM(2000) 274) was endorsed by the European Parliament on 18 May".

164 Notes 22 and 23 above.

165 Automatic consequence of the decision of the EU Council of 3 Mai 1998 and Article 121 para. 1 phrase 3 TEC. 
Poland, Romania, Sweden, and the United Kingdom. They are the "Member States with a derogation". 166

\subsection{EURO BANKNOTES AND COINS}

The euro is the only official currency in the Union. Euro banknotes and euro coins are legal tender in all Member States whose currency is the euro; the only legal tender. ${ }^{167}$ All other currencies or means of payment had to cease to fulfil this function. Euro banknotes may be issued by the ECB or the national central banks, Article 128(1) sentence 2 TFEU. However, without authorisation by the ECB, no euro banknote may be issued. It is an exclusive right of the ECB, Article 128(1), 282(3) sentence 2 TFEU. In this way, the ECB has effective control over the kind and volume of euro banknotes, even though the actual production is cared for by the national central banks as the "operative arm" of the Eurosystem. All notes are identical no matter where they are produced. These banknotes are the only banknotes which have the status of legal tender within the Union, Article 128(1) sentence 3 TFEU.

In contrast, euro coins are issued by the Member States and have different designs on one side of the coin. Approval by the ECB is required regarding the volume of the issue, Articles 128(2), 282(3) sentence 2 TFEU, thus retaining control over the volume of central bank money.

\subsection{THE EURO OUTSIDE THE EU}

Usually, sovereign states have their own currencies and central banks, and some of these currencies are pegged to the euro. ${ }^{168}$ Some countries use the euro as legal tender upon the basis of formal agreements following Article 219(3) TFEU, with the right to mint euro coins, such as Andorra, Monaco, San Marino, and the Vatican, as a source of revenue for their budgets. ${ }^{169}$ Some countries use the euro as legal tender without permission. ${ }^{170}$ In some areas,

\footnotetext{
166 For more details, see Section 1.2.3. above.

167 Now Article 128 para. 1 TFEU.

168 In Europe: Macedonia and Bosnia \& Herzegovina (indirectly via the former Deutsche Mark); in Africa: Cape Verde, São Tomé and Príncipe, the Comores, and all countries using the CFA.

169 For details and references see: Monetary and exchange rate arrangements of the euro area with selected third
} 
it is used de facto as currency without being legal tender. ${ }^{171}$ Its use in the overseas territories of Member States and associated countries follows complex rules. ${ }^{172}$

\section{EXIT, EXCLUSION, OR PARALLEL CURRENCIES IN THE EUROZONE?}

As the Monetary Union is an integral part of the $\mathrm{EU}^{173}$ and each Member State is obliged to introduce the euro, ${ }^{174}$ exit from the eurozone, which has been discussed quite frequently by economists, politicians and the media, is legally not possible and economically questionable (Sub-section 4.1). ${ }^{175}$ The introduction of a new currency parallel to the euro by a Member State which has introduced the euro is also forbidden since the Member States lack the competence to implement such a measure (Sub-section 4.2). Neither exit, nor the implementation of a parallel currency may be permitted by the organs of the EU or of the Member States (Sub-section 4.3). The exclusion of a Member State from the EU or the Monetary Union is highly questionable from a legal point of view (Sub-section 4.4). This does, however, not imply that there are no possibilities for sanctions. Any illegal action taken within this framework will have at least serious consequences for the affected claims and property rights (Sub-section 4.5).

\subsection{EXIT OR WITHDRAWAL}

Pursuant to Article 50(1) TEU, any Member State may "decide to withdraw from the Union in accordance with its own constitutional requirements”. However, a partial or total exit

countries and territories, European Central Bank (2006), p. 87; Helmut SiEKMANN (2013), Einführung [introduction], margin no. 58 and 59.

170 Montenegro, Kosovo.

${ }^{171}$ For example, in Zimbabwe, or on the British military bases Akrotiri and Dekelia on Cyprus, although the UK does not belong to the eurozone.

172 For details, see HeLMUT SIEKMANN (2012), p. 359, 360; id. (2013), Einführung [introduction], margin no 5359; id., Protocol (No 17) no 6-8; id., Protocol (No 18) no 14, 15, 18, 20, 21.

173 Section 2.1. above.

174 Section 1.2.2. above.

175 BEATRICE WEDER Di MAURo (2010), p. 99 et seq., points out that monetary systems that provide an exit option are inherently instable. HAL S. SCOTT (1998) discusses the situation "when the euro falls apart" pretending this would be the natural (and legal?) course of the development. Implicitly he assumes that a withdrawal is legally possible as he assesses the consequences of a withdrawal or breakup. This was written, however, before the introduction of Article 50 TEU. 
solely from the eurozone is not provided for. Before the introduction of this clause into the primary law by the Treaty of Lisbon, ${ }^{176}$ it had been debated for quite some time whether a Member State could legally leave the European Economic Community (EEC) or - later - the European Communities (EC). This was also discussed in view of a partial renouncement. The legal literature of the time predominantly denied the possibility of an exit or withdrawal. ${ }^{177}$ In cognisance of this controversy, consensus was finally reached with the introduction of Article 50 TEU. It was meant as a final answer to all questions arising from this problem. ${ }^{178}$ As a consequence, Article 50 TEU has to be judged as being conclusive.

From this it follows that a recourse to the Vienna Convention on the Law of Treaties ${ }^{179}$ or to general rules of the law of nations (clausula rebus sic stantibus) is prohibited. ${ }^{180}$ The application of the Conventions is interdicted in the first place for reasons of the EU law. Furthermore, the provisions of the Vienna Convention regulating the termination of a treaty ${ }^{181}$ are also not applicable because of the subsidiarity of the following provisions:

- Article 54 refers expressly to the provisions of the treaty in question:

"The termination of a treaty or the withdrawal of a party may take place: (a) in conformity with the provisions of the treaty; or (b) at any time by consent of all the other parties after consultations with the other contracting States.”

\footnotetext{
${ }^{176}$ Note 26 above.

177 Rudolf Streinz (2012a), Article 50 TEU, margin no. 3 with further references.

178 Oliver Dörr (2011), Article 50 TEU, margin no. 3; Koen Lenaerts and Piet Van Nuffel (2011), margin no. 6015; Helmut Siekmann (2012), p. 376.

179 Chapter XXIII Title 23.1 of 23 May 1969, entry in force on 27 January 1980; official publication in three languages as appendix to: Gesetz zu dem Wiener Übereinkommen vom 23. Mai 1969 über das Recht der Verträge vom 3. August 1985, Federal Law Gazette, Part II (Bundesgesetzblatt Teil II) 1985, p. 926.

180 Claudia Annacker (1998), pp. 59-61, denies the validity of the rules of the law of nations inside a supranational organisation, i.e. among the members inter se; Christian Calliess (2011b), Article 50 TEU margin no. 13, understanding the consent of Member States to the Treaty of Lisbon as an implicit renunciation of any exit rights; Ulrich Becker (2012), Article 356 TFEU margin no. 5 without reservation; disagreeing: Bernhard Kempen (2012), Article 140 TFEU margin no. 32 without regarding Article 50 TEU; Ulrich Häde (2011), Article 140 TFEU margin no. 63 without reasoning; Oliver Dörr (2011), margin no. 3 and 4, but still considering the provision as constitutive; Michael Rodi (2012), Article 140 TFEU margin no. 4 without considering Article 50 TEU.

${ }^{181}$ Section 3: Termination and Suspension of the Operation of Treaties.
} 
- Article 56(1) clearly restricts the grounds for the termination of a treaty:

"A treaty which contains no provision regarding its termination and which does not provide for denunciation or withdrawal is not subject to denunciation or withdrawal unless (a) it is established that the parties intended to admit the possibility of denunciation or withdrawal; or (b) a right of denunciation or withdrawal may be implied by the nature of the treaty."

Both do not hold in the case of the European Monetary Union.

- Article 70(1) accordingly delineates the consequences:

"1. Unless the treaty otherwise provides or the parties otherwise agree, the termination of a treaty under its provisions or in accordance with the present Convention (a) releases the parties from any obligation further to perform the treaty; (b) does not affect any right, obligation or legal situation of the parties created through the execution of the treaty prior to its termination.”

Since the Treaty of Lisbon, Paragraph 1 of Article 56 of the Vienna Convention now clearly blocks Member State exit or withdrawal upon the basis of the Convention in the context of the EU. The Treaty of Lisbon created a provision which explicitly regulated withdrawal from the Union, but does not provide for exit solely from the EMU, and thus there is no space for the application of Article 56 of the Convention. In addition, it is highly questionable whether this convention is applicable to a supranational organisation such as the EU. $^{182}$

In effect, the provisions on a "fundamental change of circumstances" also do not allow exit or withdrawal from the eurozone. Aside from the highly problematical applicability of the Vienna Convention in the context of the EU, the pre-requisites of its Article 62 are not fulfilled: ${ }^{183}$ Article $62(1)$ of the Convention stipulates, in the first place, that:

182 Cf. the material presented by RALF GÜNTER WETZEL and DIETRICH RAUSCHNING (1978), pp. 390-395. HAL S. ScotT (1998), p. 241, discussing in depth Article 56 of the Vienna Convention on the Law of Treaties expresses doubts whether the provisions of paragraph 1 of the article are met regarding the EU law but does not come to a clear result (p. 214). This was, however, before the insertion of Article 50 TEU.

${ }^{183}$ This article is considered to be a codification of the general law of nations: JöRG P. MÜLLER (1971), p. 217. 
“a fundamental change of circumstances (...) has occurred with regard to those existing at the time of the conclusion of a treaty (...) which was not foreseen by the parties." 184

Nor will recourse to the general clausula rebus sic stantibus allow exit. It, too, is foreclosed. $^{185}$

The problems with the fiscal sustainability or competitiveness of a Member State introducing the euro had been foreseen by the parties of the Treaty of Maastricht as the admission procedure imposed admission criteria, ${ }^{186}$ and the expansion of the cohesion and structural funds ${ }^{187}$ clearly prove. Article 126 TFEU and the Protocol on excessive deficits also regulate the matter. In addition, Article 62(2) of the Convention expressly interdicts a fundamental change of circumstances being invoked as a ground for terminating or withdrawing from a treaty "if the fundamental change is the result of a breach by the party invoking it”. This would be the case not only for Greece ${ }^{188}$ but also for other Member States which do not fulfil the rules on fiscal soundness, as specified in Article 126(1) TFEU and the ensuing secondary law.

An opt-out has been granted specifically for the UK and Denmark in the Protocols to the Treaty of Maastricht. If, in general, an exit from the euro area were permissible, these legal acts would have been totally superfluous.

A withdrawal from the obligations of the Monetary Union allowing the reintroduction of a currency of its own by a Member State would therefore have to be judged as illegal $^{189}$ with severe economic and legal consequences. ${ }^{190}$

\footnotetext{
${ }^{184}$ For details, see JÖRG P. MÜLLER (1971), pp. 217-226.

185 Christian CALLiess (2011b), Article 50 TEU margin no. 13.

186 Section 1.3.4. above.

${ }^{187}$ Section 1.4.3. (1) above.

${ }^{188}$ More Section 4.2. below.

189 With in depth analysis: Chiara Zilioli (2005), pp. 126, 132; PhoEbus Athanassiou, (2009), p. 21; HELMUT SiEKMANN (2013), Einführung [introduction] margin no. 48; in effect similarly: PAUL KIRCHHOF (1994), p. 72; HUGO J. HAHN and UlRICH HÄDE (2010), § 26 margin no. 7 et seq; disagreeing - although hesitating - without any legal reasoning: MARTIN SEIDEL (2007), p. 617: despite the distinct missing of an exit clause like in the system of the European Monetary System (EMS): probably enabled by "unwritten community law"; questioning but without a clear solution PETER BEHRENS (2010), p. 121; unclear: ULRICH HÄDE (2011), Article 140 TFEU margin no. 59 and 63. The GFCC mentions in its Maastricht-judgment a
} 


\subsection{The InTroduction of a Parallel CurRency}

It has also been proposed to maintain the euro in a distressed Member State such as Greece but also to introduce a second (new) currency parallel to the euro. ${ }^{191}$ It is highly questionable whether such a measure could mitigate the financial problems of the country as all financial claims are still denominated in euro. National legislation to change this, would probably be void as breaching national and international civil rights statutes. Furthermore, intricate problems of international private law would also have to be solved.

In any case, such a measure would also be illegal from the point of view of the primary law of the Union. Euro banknotes are the only legal tender within the Member States whose currency is the euro, Article 128(1) sentence 3 TFEU. Also the secondary law categorically forbids a currency other than the euro. ${ }^{192}$ As the sovereignty in monetary affairs of the euro Member States has been transferred to the Union, "all national powers of legislation and action in the monetary law field came to an end when the euro was introduced in these states". 193

A statute trying to introduce a new drachma, for example, as legal tender would be void, with the result that nobody would have to accept it. For this reason, the action would also be useless from an economic point of view.

right or even an obligation to leave the EMU as ultima ratio, however, only as an obiter dictum without sufficient reasoning, BVerfGE 89, 155 (204). Whereas from its Lisbon-judgment can be inferred that an exit would not be compatible with German constitutional law, BVerfGE 123, 267.(346 f.).

More Section 4.5. below.

${ }^{191}$ For example Thomas Mayer (2014), p. 35; idem (2015).

192 Article 2 sentence 1 Council Regulation (EC) No 974/98 on the introduction of the euro, Official Journal of 11 May 1998, L 139/1; cf. Charles Proctor (2012), margin no. 29.13 emphasizing that the euro has been made the sole currency in the participating Member States judging it as the lex monetae of the eurozone (margin no. 29.10.

193 Charles Proctor (2012), margin no. 31.10. 


\subsection{EXCLUSION}

\subsubsection{General Rules}

An exclusion from the eurozone by an act of the EU or the eurogroup is not allowed as the needed legal basis for such an onerous measure is not visible. The primary law does not provide a statutory basis for such a sanction. ${ }^{194}$ Also Article 7 TEU could not serve as an instrument for an exclusion for three main reasons:

(1) It contains an elaborated procedure for enforcing the fundamental values of the EU and only them. It is restrained to the values laid down in Article 2 TEU such as respect for human dignity, freedom, democracy, equality, the rule of law and the respect for human rights. The breach of the rules for the economic and monetary policy as such does not belong to it. Only a serious aberration from the various aspects of the procedural or substantive requirements set up by the rule of law might suffice this requirement. This is, however, not yet in sight;

(2) In line with the argumentation above, it does not provide a basis for a separate exclusion from the Monetary Union;

(3) Moreover, it does not even provide a basis for an exclusion from the EU as its most severe sanction for "a serious and persistent breach by a Member State" is the suspension of "certain rights of the representatives of the government of that Member State in question including the voting rights”, Article 7(3) sentence 1 TEU.

The common breach of EU law by a Member State has been specifically regulated in Articles 258 and 259 TFEU. The exclusion is also not a sanction foreseen in the detailed procedure laid down there.

The described statutory provisions have to be judged as conclusive. A recourse to rules of the law of nations is not allowed. ${ }^{195}$

194 Koen Lenaerts and Piet VAn Nuffel (2011), margin no 6-014; in general, also: Christian CALLIESS (2011b), Article 50 TEU, margin no. 12, 13 but exception for extreme cases.

195 Juliane Kокотт (2012), Article 356 margin no. 6; partially disagreeing: RudoLf STREINZ (2012a), Article 50 TEU margin no. 13, considering it for an exclusion from the EU (not the EMU!) in "extreme cases"; also MATthias PeChSTEIN (2012), Article 7 margin no. 23 without reasoning; unclear Christian CALLIESS (2011b), Article 50 TEU margin no. 17, 21 (advice to withdraw pursuant Article 50 TEU). 


\subsubsection{Renunciating the Acts of Admittance to the Euro}

It has been deliberated ${ }^{196}$ that the legal acts admitting a country to the euro, could be renounced, in specific by amending the regulation about the introduction of the single currency ${ }^{197}$, not regarding whether they were obtained by fraud or misrepresentation. Even if it could be true that legal acts might be revocable by the competent institutions as actus contrarii $^{198}$ this does not hold in the course of introducing the single currency in a staggered procedure prescribed by the Maastricht Treaty. Those acts were clearly designed to be complete, unconditional, and irrevocable. ${ }^{199}$ Otherwise, it would have left the door open for speculative pressure. All details were meticulously regulated. A way back was not contemplated and would have been contrary to the principle dominating the formation of the EU: an always closer integration; and not a way back and forth, Article 1 TEU. ${ }^{200}$

\subsubsection{The Specific Circumstances in the Case of Greece}

In the case of Greece, however, it could be argued that the permission to introduce the euro was obtained as a result of fraud, misrepresentation, or force. It might suffer from a serious legal defect allowing the removal from the eurozone. In technical legal terms it could be renounceable, voidable, or invalid from the beginning on. In the case of Greece it would have to be examined whether the decision of the Council of 19 June 2000 ordering that the derogation in favour of Greece shall be abrogated with effect from 1 January 2000, ${ }^{201}$ which in effect meant admitting Greece to the euro area, suffers from such a serious legal flaw due

\footnotetext{
196 Peter Behrens (2010), p. 121; Christoph Herrmann (2010), p. 417.

197 Council Regulation (EC) No 974/98 on the introduction of the euro, Official Journal of 11 May 1998 , L 139/1.

198 This is true even if Article 3 TEU may not be interpreted as a general interdiction of regression in the course of European integration, see, for his ULRICH BECKER (2012), Article 3 TEU margin no. 10, but without reasoning.

199 Charles Proctor (2012), margin no. 29.10; CHRIstoph HERRMANn (2010), p. 417.

200 Christian CALliess (2011b), Article 1 TEU margin no. 12: interdiction of regression.

201 Article 1 of the decision (note 163 above).
} 
to fraud or misrepresentation on the part of Greece ${ }^{202}$ that it would be void or could be abolished.

The rules of the Vienna Convention on the invalidity of treaties as a consequence of error $^{203}$ or fraud, ${ }^{204}$ or its breach, ${ }^{205}$ may be worth considering but will probably not be applicable. The EU is - despite its origin in treaties - more than just a contractual arrangement. Also the termination or suspension of the operation of a treaty following Article 60 of the Convention because of its breach or non-fulfilment of obligations by one of the parties may be barred for the same reasons. ${ }^{206}$

It could be discussed if and to which extent the general rules contained in the (private) law of contracts on the validity of the declaration of intention may be applied to sovereign acts. In general, also the law of nations accepts force, ${ }^{207}$ error, ${ }^{208}$ and fraud ${ }^{209}$ as flaws that might lead to the invalidity of a sovereign act. Even more intricate is the question whether those rules are applicable to acts designing the setup of an institution and its operation. Institutions, like the European Union or its subset, the Monetary Union, are designated to be stable and permanent and cannot work under the lasting danger of being dismantled because of defects in the founding legal acts. At least the span of time between the disclosure of such a defect and ensuing legal actions has to be limited. Finally the subsequent behaviour of the victim of fraud or misrepresentation has to be taken into account. ${ }^{210}$ Granting financial support for Greece fully aware of the facts of a misrepresentation might remedy the legal defects of the admittance decision. ${ }^{211}$ Whereas, the principle of trust and good faith within

\footnotetext{
202 The questionable actions of the Greek government to obtain admittance are described by the Commission in its "Report on Greek Government Deficit and Debt Statistics" of 8 January 2010, COM(2010) 1 final; detailed analysis by: Theodore Pelagidis and Michael Mitsopoulos (2014); George C. Bitros (2013), especially pp. 13-17.

203 Article 48.

204 Article 49.

205 Article 60.

206 Accepted by the law of nations as general principle, see Franz Pfluger (1936), p. 129 also mentioning already the exit from a multilateral agreement (p. 131 et seq.)

207 IBID., pp. 78-88.

208 IBID., pp. 88-91.

209 IBID., pp. 91-93.

210 Regulated in Article 45 of the Vienna Convention.

${ }^{211}$ In general, ClAUDIA ANNACKER (1998), p. 273 et seq.
} 
organizations $^{212}$ might require that Greece discharges its (new) obligations within this context. A failure to do so might also lead to serious legal consequences.

By all means, the general or the contractual law of nations is not applicable in case the EU contains a specific regulation of the problem. This is to be found in Article 7 TEU which provides in a staggered procedure the suspension of membership rights as most severe sanction. $^{213}$ An exclusion is not provided and would be illegal. ${ }^{214}$

\subsection{Permission to InTROdUCE A NeW CURRENCY}

An exit from the Monetary Union or the introduction of a parallel currency may also not be permitted on the basis of Article 3(1)(c) TFEU. This clause does not comprise the power to amend primary law. ${ }^{215}$ This would, however, be indispensable because of Article 50 TEU and Article 128 TFEU. It has to be kept in mind, the euro banknotes are "the only such notes to have the status of legal tender within the Union”, Article 128(1) sentence 3 TFEU.

\subsection{CONSEQUENCES OF AN ILLEGAL EXIT FROM THE EUROZONE}

Serious and hard to calculate problems would above all arise for the debt denominated in euro in case the new currency is introduced despite the contradicting rules of EU law. ${ }^{216}$

It is already highly questionable, whether such debt would automatically be transformed into debt denominated in the new currency (e.g. nea drachme); especially as the old currency will continue to exist. The national government may, however, try to change the denomination of the existing debt by a unilateral administrative or legislative act. This act would have to be judged as void since the Member State whose currency is the euro does not have competences in monetary affairs any more. As its withdrawal from the Monetary Union

\footnotetext{
212 Generally accepted JÖRG P. MÜLLER (1971), p. 227 et seq.

${ }^{213}$ Article 7 TEU margin no. 3 with some caveats; Article 356 TFEU margin no. 5, 7 with further references; in general also Matthias Ruffert (2011), Article 7 TEU margin no. 31 et seq., with further references.

214 Koen Lenaerts and Piet VAn NufFel (2011), margin no. 6-014; Juliane KoKOtT (2012), Article 356 TFEU margin no. 6 with further references.

215 ULRICH HÄDE (2011), Article 140 TFEU margin no. 60.

${ }^{216}$ For an extensive analysis of the severe consequences, in specific for all contractual obligation denominated in euro, see WOLFGANG ERNST (2012), p. 50, et seq., 57; FRANK VisCHER (2010), Section 18.
} 
or the introduction of a new (parallel) currency are illegal the EU continues to command the exclusive competence in all monetary affairs, Article 3(1)(c) TFEU. ${ }^{217}$ Acts of a Member State in this field are void or at least illegal as well.

In general, it can be assumed that EU law is the lex monetae ${ }^{218}$ governing obligations originating in a Member State. A change of the currency would at least be ineffective in view of the objective to reduce the burden of debt. ${ }^{219}$ This result is not affected by the fact whether the law of the re-denominating country or a foreign law is governing the underlying contracts; for example it would be irrelevant whether a bond has been issued pursuant to the law of the United Kingdom or of Greece in case the Hellenic Republic would introduce a new currency. The fact according to which law the obligation has come into existence may only be used as criterion for determining the lex monetae in situations of uncertainty about the applicable currency. ${ }^{220}$ This uncertainty is, however, not given in a case when a government by sovereign act changes the denomination referred to in a contract to another currency, e.g., from euro to "new drachme". 221

\section{REFERENCES}

Annacker, Claudia (1998): Der fehlerhafte Rechtsakt im Gemeinschafts- und Unionsrecht, Vienna and New York, Springer.

217 Section 1.2.1. above.

${ }^{218}$ For definition and function, see, already, F.A. MANN (1992), p. 219 et seq., 272, 278; later: CHARLES PROCTOR (2012), margin no. 32.16; FRANK VISCHER (2010) margin no. 358-364; WOLFGANG ERNST (2012), pp. 52-55.

219 Without referring to this crucial clause HAL S. SCOTT (1998), p. 223, comes to a similar conclusion: "Note that if reference was made to EU law as lex monetae, ... re-denomination would be ineffective." Nevertheless, he does not state a clear result because of the lack of precedents in the case of a surviving monetary union. ARTHUR NuSSBAum (1925), p. 161, is searching for a line of discrimination when a sovereign ruler introduces a new currency but only in a fraction of the territory and the old currency continuing to exist in the rest of the territory. He pre-supposes, however, that the change of the monetary system has been performed lawfully by exercising a sovereign right.

220 Already described by Arthur Nussbaum (1925), pp. 228-231.

${ }^{221}$ HAL S. SCOTT (1998), p. 223, supposes that only foreign courts would apply the lex monetae. This is, however, an irrevelant guess in delivering an opinion on the merits of a legal question. He cites Mann for leaving the decision to the proper law of the contract. In fact it is, however, in the first place a question of the sovereign right which has been decided by the primary law of the Union. 
Athanassiou, Phoebus (2009): "Withdrawal and Expulsion from the EU and EMU”, ECB Legal Working Papers Series No. 10, Frankfurt aM.

Bandilla, Rüdiger (2012): “Article 126 TFEU” in: Eberhard Grabitz, Meinhard Hilf and Martin Nettesheim (eds), Das Recht der Europäischen Union, Munich, C.H. Beck.

Becker, Ulrich (2012): “Article 3 TEU, Article 356 TFEU”, in: Jürgen Schwarze (ed), EUKommentar, 3rd ed, Baden-Baden, Nomos Verlag.

Behrens, Peter (2010): “Ist ein Ausschluss aus der Euro-Zone ausgeschlossen?”, Europäische Zeitschrift für Wirtschaftsrecht, (4): p. 121.

Bitros, George C. (2013): "European Union Failures in Greece and some Possible Explanations”, MPRA Paper No. 45017 of 13 March 2013.

Blanke, Hermann-Josef (2012): "Die Europäische Wirtschafts- und Währungsunion zwischen Krisenanfälligkeit und Reform”, in: Arno Scherzberg (ed), 10 Jahre Staatswissenschaftliche Fakultät, Berlin, Walter de Gruyter, pp. 70-121.

Borger, Vestert (2013): “The ESM and the European Court's Predicament in Pringle”, German Law Review, 14 (1): pp. 113-127.

Calliess, Christian (2011a): "Perspektiven des Euro zwischen Solidarität und Recht - Eine rechtliche Analyse der Griechenlandhilfe und des Rettungsschirms”, Zeitschrift für europarechtliche Studien, (02): pp. 213-282.

Calliess, Christian (2011b): “Article 1 and 50 TEU, Article 2 TFEU”, in: Christian Calliess and Matthias Ruffert (eds), EUV/AEUV, 4th ed, Munich, C.H. Beck.

Calliess, Christian (2013): "Der ESM zwischen Luxemburg und Karlsruhe”, Neue Zeitschrift für Verwaltungsrecht, (03): pp. 97-105.

Degenhart, Christoph (2012): "Missachtung rechtlicher Vorgaben bei der Umsetzung der Währungsunion”, Bonner Rechtsjournal, (02): pp. 157-163.

Degenhart, Christoph (2013): "Missachtung rechtlicher Vorgaben bei der Umsetzung der Währungsunion”, in: Thomas M.J. Möllers and Franz-Christoph Zeitler (eds), Europa als Rechtsgemeinschaft - Währungsunion und Schuldenkrise, Tübingen, Mohr Siebeck, pp. 85-100.

de Grauwe, Paul (2010): "How to Embed the Eurozone in a Political Union, in: Richard Baldwin, Daniel Gros and Luc Laeven (eds), Completing the Eurozone Rescue: What More Needs to Be Done, London, Centre for Economic Policy Research, pp. 29-32.

de Gregorio Merino, Alberto (2012): "Legal Developments in the Economic and Monetary Union during the Debt Crisis: The Mechanisms of Financial Assistance”, Common Market Law Review, 49 (05): pp. 1613-1645.

Deutsche Bundesbank (2005a): “Comments on Reforming the Stability and Growth Pact”, Monthly Report, January 2005, pp. 37-43.

Deutsche Bundesbank (2005b): "The Changes to the Stability and Growth Pact", Monthly Report, April 2005, pp. 15-21.

Dörr, Oliver (2011): “Article 50 TEU”, in: Eberhard Grabitz, Meinhard Hilf, and Martin Nettesheim (eds), Das Recht der Europäischen Union, Munich, C.H. Beck (loose leaf). 
Doukas, Dimitrios (2005): "The Frailty of the Stability and Growth Pact and the European Court of Justice: Much Ado about Nothing?”, Legal Issues of Economic Integration, 32 (3): pp. 293-312.

Dutzler, Barbara (2003): The European System of Central Banks: An Autonomous Actor? The Quest for an Institutional Balance in the EMU, Vienna-New York, Springer.

Dutzler, Barbara, and Angelika Hable (2004): "Das Urteil des Europäischen Gerichtshofs zum Stabilitäts- und Wachstumspakt - eine Klarstellung?”, in: Integration Vierteljahreszeitschrift des Instituts für Europäische Politik, 27 (4): pp. 301-316.

Elicker, Michael and Veris-Pascal Heintz (2012), "Zum verfassungsrechtlichen Schutz des Geldwertes - Zugleich eine Besprechung der Entscheidung zur Griechenland-Hilfe -, Deutsches Verwaltungsblatt, (03): pp. 141-144.

Ernst, Wolfgang (2012): "Privatrechtliche Folgen eines Ausscheidens einzelner Staaten aus der Euro-Währung - ein Problemaufriss”, Zeitschrift für Wirtschaftsrecht, 33 (2): pp. 49-58.

European Central Bank (2005): "The Reform of the Stability and Growth Pact", Monthly Bulletin, August 2005, pp. 59-73.

European Central Bank (2006): "Monetary and Exchange Rate Arrangements of the Euro Area with Selected Third Countries and Territories”, Monthly Bulletin, April 2006, pp. 87-97.

European Central Bank (2011a): "The Reform of Economic Governance in the Euro Area Essential Elements”, Monthly Bulletin, March 2011, pp. 99-119.

European Central Bank (2011b): Monetary Policy of the ECB, Frankfurt aM, ECB.

European Central Bank (2013); "Economic and Monetary Developments, Box 6: The "Twopack” Regulations to Strengthen Economic Governance in the Euro Area“, Monthly Bulletin, April 2013, pp. 53-55.

European Commission (2006): “One Currency for one Europe - The Road to the Euro", Brussels.

European Commission (2014a): "Communication from the Commission to the European Parliament, the Council, the European Central Bank, the European Economic and Social Committee and the Committee of the Regions, Economic governance review, Report on the application of Regulations (EU) no 1173/2011, 1174/2011, 1175/2011, 1176/2011, 1177/2011, 472/2013 and 473/2013”, 28. November 2014, COM(2014) 905 final, Annex 1.1.

European Commission (2014): “Report on Public Finances in EMU 2014”, Brussels.

Faßbender, Kurt (2010): "Der europäische 'Stabilisierungsmechanismus' im Lichte von Unionsrecht und deutschem Verfassungsrecht", Neue Zeitschrift für Verwaltungsrecht, (13): pp. 799-803.

Fögen, Herrmann (1969): Geld- und Währungsrecht, Munich, C.H. Beck.

Frenz, Walter, and Christian Ehlenz (2010): "Schuldenkrise und Grenzen der europäischen Wirtschaftspolitik”, Europäisches Wirtschafts- und Steuerrecht, (06): pp. 211-215. 
Fried, Raymond J. (2003): "Secession from the European Union: Checking out of the proverbial 'Cockroach Motel’”, Fordham International Law Journal, 2003-2004 (27): pp. 590-641.

Gaitanides, Charlotte (2005): Das Recht der Europäischen Zentralbank, Tübingen, Mohr Siebeck.

Gaitanides, Charlotte (2013): Article 126, in: Helmut Siekmann (ed), Kommentar zur Europäische Währungsunion, Tübingen, Mohr Siebeck.

Glatzl, Stefan (2009): Geldpolitik und Bankenaufsicht im Konflikt, Baden-Baden, Nomos Verlag.

Häde, Ulrich (1996): "Ein Stabilitätspakt für Europa? Zur Zulässigkeit völkerrechtlicher Verträge zwischen den Mitgliedstaaten der EU”, Europäische Zeitschrift für Wirtschaftsrecht, (07): pp. 138-143.

Häde, Ulrich (2010): "Die europäische Währungsunion in der internationalen Finanzkrise An den Grenzen der euorpäischen Solidarität?”, Europarecht, (06): pp. 854-862.

Häde, Ulrich (2011): “Article 139 and 140 TFEU”, in: Christian Calliess and Matthias Ruffert (eds), EUV/AEUV, 4th ed, Munich, C.H. Beck.

Hadjiemmanuil, Christos (1996): The European Central Bank and Banking Supervision, London, International Finance \& Tax Law Unit.

Hahn, Hugo J., and Ulrich Häde (2010): Währungsrecht, 2nd ed, Munich, C.H. Beck.

Hansmeyer, Karl-Heinrich (1972): “§ 1 Stabilitätsgesetz” in: Klaus Stern, Paul Münch and Karl Heinrich Hansmeyer (eds), Gesetz zur Förderung der Stabilität und des Wachstums der Wirtschaft, 2nd ed, Stuttgart-Berlin-Cologne-Mainz, Kohlhammer.

Hartmann, Gustav (1868): Ueber den rechtlichen Begriff des Geldes und den Inhalt von Geldschulden, Braunschweig,Verlag der Hofbuchhandlung von Eduard Leibrock.

Hattenberger, Doris (2012): “Article 122 TFEU”, in: Jürgen Schwarze (ed), EU-Kommentar, 3rd ed, Baden-Baden, Nomos Verlag.

Hentschelmann, Kai (2009): Der Stabilitäts- und Wachstumspakt, Baden-Baden, Nomos Verlag.

Hentschelmann, Kai (2011): "Finanzhilfen im Lichte der No Bailout-Klausel Eigenverantwortung und Solidarität in der Währungsunion”, Europarecht, (02): pp. 282-312.

Herrmann, Christoph (2010a): Währungshoheit, Währungsverfassung und subjektive Rechte, Tübingen, Mohr Siebeck.

Herrmann, Christoph (2010b): “Griechische Tragödie - der währungsverfassungsrechtliche Rahmen für die Rettung, den Austritt oder den Ausschluss von überschuldeten Staaten aus der Eurozone”, in: Europäische Zeitschrift für Wirtschaftsrecht, (11): pp. 413418.

Herrmann, Christoph (2012): "Die Bewältigung der Euro-Staatsschuldenkrise an den Grenzen des deutschen und europäischen Währungsverfassungsrechts”, Europäische Zeitschrift für Wirtschaftsrecht, (21): pp. 805-812. 
Heun, Werner (1998): “Die Europäische Zentralbank in der Europäischen Währungsunion”, Juristen Zeitung, (18): pp. 866-876.

Heun, Werner and Alexander Thiele (2012): "Verfassungs- und europarechtliche Zulässigkeit von Eurobonds”, Juristen Zeitung, (20): pp. 973-982.

Hirsch, Fred (1967): Money International, New York, Penguin Press.

Issing, Otmar (2008a): “The Euro - A Currency without a State”, Center for Financial Studies Working Paper No. 2008/51.

Issing, Otmar (2008b): “The Euro: Does a Currency Need a State?”, International Finance, 11 (03): pp. 297-310.

Issing, Otmar (2008c): The Birth of the Euro, Cambridge, Cambridge University Press.

James, Harold (2012): Making the European Monetary Union, Cambridge, Massachusetts and London, England. The Belknap Press of Harvard University Press.

Kempen, Bernhard (2012), “Article 119, Article 139, Article 140 TFEU”, in: Rudolf Streinz (ed), EUV/AEUV, 2nd ed, Munich, C.H. Beck.

Kirchhof, Paul (1994): "Die Mitwirkung Deutschlands an der Wirtschafts- und Währungsunion”, in: Authors (eds), Steuerrecht, Verfassungsrecht, Finanzpolitik, Festschrift für Franz Klein, Cologne, Otto Schmidt, pp. 61-83.

Knapp, Georg Friedrich (1905): Staatliche Theorie des Geldes, Leipzig, Duncker \& Humblot.

Kokott, Juliane (2012): “Article 356 TFEU”, in: Rudolf Streinz (ed), EUV/AEUV, 2nd ed, Munich, C.H. Beck.

Kotzur, Markus (2004): "Urteilsanmerkung: EuGH, 13.7.2004 - Rs. C-27-04 Kommission der EG - Rat der EU - Zur Aussetzung der Defizit-Verfahren gegen Deutschland und Frankreich”, Juristen Zeitung, (21): pp. 1069-1074.

Kube, Hanno, and Ekkehard Reimer, (2010): "Grenzen des Europäischen Stabilisierungsmechanisumus”, Neue Juristische Wochenzeitschrift, (27): pp. 19111916.

Kube, Hanno (2012): "Rechtsfragen der völkervertraglichen Euro-Rettung”, Zeitschrift für Wirtschafts- und Bankrecht, (06): pp. 245-253.

Lastra, Rosa María (2006): Legal Foundations of International Monetary Stability, Oxford, Oxford University Press.

Lenaerts, Koen, and Piet Van Nuffel (2011): European Union Law, 3rd ed, London, Sweet \& Maxwell.

Louis, Jean-Victor (1995): “L’Union économique et monétaire”, in: Commentaire Mégret, Le droit de la CEE, 2nd ed, vol. 6, Brussels, Editions de l’Université de Bruxelles.

Louis, Jean-Victor (2010): Guest Editorial: “The No-bailout Clause and Rescue Packages”, Common Market Law Review, 47 (04): pp. 971-986.

Mann, F.A. (1992): The Legal Aspect of Money, 5th ed, Oxford, Clarendon Press.

Mayer, Thomas (2010): "What more do European Governments Need to Do to Save the Eurozone in the Medium Run?”, in: Richard Baldwin, Daniel Gros and Luc Laeven 
(eds), Completing the Eurozone Rescue: What More Needs to Be Done, London, Centre for Economic Policy Research, pp. 49-53.

Mayer, Thomas (2014), Die neue Ordnung des Geldes: Warum wir eine Geldreform brauchen, Munich, Finanzbuch Verlag.

Mayer, Thomas (2015): “Eine Parallelwährung für Griechenland”, Frankfurter Allgemeine, 24 January 2015.

Meade, J.E. (1957): “The Balance-of-Payments Problems of a European Free-Trade Area”, The Economic Journal, 67 (268): pp. 379-396.

Möller, Alex (1969): Gesetz zur Förderung und Stabilität und des Wachstums der Wirtschaft und Art. 109, 2nd ed, Hannover, Verlag für Literatur und Zeitgeschichte.

Müller, Jörg P. (1971): Vertrauensschutz im Völkerrecht, Cologne-Berlin, Heymann.

Mundell, Robert A. (1997): "Money and the Sovereignty of the State", paper prepared for the International Economic Association in Trento, 4-7 September 1997.

Nettesheim, Martin (2012): "Der Umbau der europäischen Währungsunion: Politische Aktion und rechtliche Grenzen”, in: Stefan Kadelbach (ed), Nach der Finanzkrise: Politische und rechtliche Rahmenbedingungen einer neuen Ordnung, Baden-Baden, Nomos Verlag, pp. 31-77.

Nettesheim, Martin (2013): "Europarechtskonformität des Europäischen Stabilitätsmechanismus”, Neue Juristische Wochenzeitschrift, (01): pp. 14-17.

Nicolaysen, Gert (1993), Rechtsfragen der Währungsunion, Berlin and New York, Walter de Gruyter.

Nicolaysen, Gert (2004): "Der EuGH zum Defizitverfahren nach Art. 104 EGV und dem 'Stabilitätspakt'”, Deutsches Verwaltungsblatt, (21): pp. 1321-1326.

Nussbaum, Arthur (1925): Das Geld in Theorie und Praxis des deutschen und ausländischen Rechts, Tübingen, Mohr Siebeck.

Palm, Ulrich (2000): Preisstabilität in der Europäischen Wirtschafts- und Währungsunion, Baden-Baden, Nomos Verlag.

Palm, Ulrich (2014): “Article 136 TFEU” in: Eberhard Grabitz, Meinhard Hilf and Martin Nettesheim (eds), Das Recht der Europäischen Union, Kommentar, Munich, C.H. Beck (loose leaf).

Pechstein, Matthias (2012): “Article 7 TEU” in: Rudolf Streinz (ed), EUV/AEUV, 2nd ed, Munich, C.H. Beck.

Pelagidis, Theodore, and Michael Mitsopoulus (2014): Greece: From Exit to Recovery, Washington DC, Brookings Institution Press.

Pfluger, Franz (1936): Die einseitigen Rechtsgeschäfte im Völkerrecht, Zürich, Schulthess.

Pipkorn, Jörn (1994): "Legal Arrangements in the Treaty of Maastricht for the Effectiveness of the Economic and Monetary Union, Common Market Law Review, (31): pp. 263291.

Potacs, Michael (2013): "Die Europäische Wirtschafts- und Währungsunion und das Solidaritätsprinzip”, Euoparecht, 2013, pp. 133-145. 
Proctor, Charles (2012): Mann on the Legal Aspect of Money, 7th ed, Oxford, Oxford University Press.

Remsperger, Hermann (2013), Zentralbankpolitik: Überforderung statt Langeweile? SAFE Policy Center, White Paper Series, No. 3.

Rodi, Michael (2012): “Article 140 TFEU” in: Christoph Vedder and Wolff Heintschel von Heinegg (eds), Europäisches Unionsrecht, Baden-Baden, Nomos Verlag.

Ruffert, Matthias (2011): “Article 7 TEU” in: Christian Calliess and Matthias Ruffert (eds): EUV/AEUV, 4th ed, Munich, C.H. Beck.

Ruffert, Matthias (2013): “Anmerkung”, Juristen Zeitung, (05): pp. 257-259.

Sachverständigenrat zur Begutachtung der gesamtwirtschaftlichen Entwicklung (1965), Jahresgutachten 1965/66, Stabilisierung ohne Stagnation, Stuttgart and Mainz, Kohlhammer.

Scheller, Hanspeter K. (2006): The European Central Bank, 2nd ed, Frankfurt aM, European Central Bank.

Schorkopf, Frank (2012), “Europas Verfasstheit im Lichte des Fiskalvertrages”, Zeitschrift für Staats- und Europawissenschaften, (1): pp. 1-29.

Schröers, Mark (2014): “'Unter 2 Prozent' vs. 'nahe 2 Prozent””, Börsen-Zeitung, 4 December 2014, p. 5.

Schuknecht, Ludger, Philippe Moutot, Philipp Rother and Jürgen Stark (2011): "The Stability and Growth Pact - Crisis and Reform”, ECB Occasional Paper Series No 129, September 2011.

Scott, Hal S. (1998): “When the Euro Falls Apart”, International Finance, 1:2/1 (2): pp. 207228.

Seidel, Martin (2007): “Ausscheiden aus der Währungsunion? - Rechtliche Fragen”, Europäische Zeitschrift für Wirtschaftsrecht, (20): p. 617.

Seidel, Martin (2011): "Europarechtsverstöße und Verfassungsbruch im Doppelpack", Europäische Zeitschrift für Wirtschaftsrecht, (07): p. 241.

Siekmann, Helmut (1985): Institutionalisierte Einkommenspolitik, Munich, Vahlen.

Siekmann, Helmut (2010): “Die Konsolidierung im Inneren muss Vorrang haben”, BörsenZeitung, 12 March 2010, p. 8.

Siekmann, Helmut (2012): “Law and Economics of the Monetary Union”, in: Thomas Eger and Hans-Bernd Schäfer (eds), Research Handbook on the Economics of the European Union Law, Cheltenham UK and Northampton, MA, USA, Edward Elgar, pp. 355-411 (Research Handbooks in Law and Economics, Series Editors: Richard A. Posner and Francesco Parisi).

Siekmann, Helmut (2013): “Introduction (Einführung), Article 119 and 130 TFEU” in: Helmut Siekmann (ed), Kommentar zur Europäischen Währungsunion, Tübingen, Mohr Siebeck.

Siekmann, Helmut (2014): “Article 88” in: Michael Sachs (ed), Grundgesetz, 7th ed, Munich, C.H. Beck. 
Siekmann, Helmut (2015): "The Legality of Outright Monetary Transactions (OMT) of the European System of Central Banks”, in: Frank Rövekamp, Moritz Bälz, Hanns Günther Hilpert (eds), Central Banking and Financial Stability in East Asia, Heidelberg, Springer, Chapter 5 (in print).

Smits, René (1997): The European Central Bank, The Hague-London-Boston MA, Kluwer Law International.

Stadler, Rainer (1996): Der rechtliche Handlungsspielraum des Europäischen Systems der Zentralbanken, Baden-Baden, Nomos Verlag.

Streinz, Rudolf (2012a): “Article 50 TEU”, in: Rudolf Streinz (ed), EUV/AEUV, 2nd ed, Munich, C.H. Beck.

Streinz, Rudolf (2012b): Europarecht, 9th ed, Heidelberg et al., C.F. Müller.

Szás, André (1999): The Road to European Monetary Union, London, Palgrave Macmillan.

Tettinger, Peter J. (1992), “Weg frei für die Europäische Währungsunion? Maastricht und die grundgesetzlichen Hürden”, Recht der Internationalen Wirtschaft, Supplement (Beilage) 3 for issue (12).

Thiele, Alexander (2013): Das Mandat der EZB und die Krise des Euro, Tübingen, Mohr Siebeck.

Thiele, Alexander (2014a): “Die EZB als fiskal- und wirtschaftspolitischer Akteur?”, Europäische Zeitschrift für Wirtschaftsrecht, (18): pp. 694-699.

Thiele, Alexander (2014b): Finanzaufsicht, Tübingen, Mohr Siebeck.

Thym, Daniel (2011): "Euro-Rettungsschirm: zwischenstaatliche Rechtskonstruktion und verfassungsgerichtliche Kontrolle”, Europäische Zeitschrift für Wirtschaftsrecht, (05): pp. 167-171.

Thym, Daniel (2013): “Anmerkung”, Juristen Zeitung, (20): pp. 259-264.

Tietje, Christian (2011): "Bilaterale Investitionsschutzverträge zwischen EU-Mitgliedstaaten (Intra-EU-BITs) als Herausforderung im Mehrebenensystem des Rechts”, Beiträge zum Transnationalen Wirtschaftsrecht, Heft 104 (Halle, January 2011).

Vischer, Frank (2010): Geld- und Währungsrecht im nationalen und internationalen Kontext, Basel, Helbing \& Lichtenhahn.

Weder di Mauro, Beatrice (2010): “Eine andere Meinung” in: Sachverständigenrat zur Begutachtung der gesamtwirtschaftlichen Entwicklung, Chancen für einen stabilen Aufschwung, Jahresgutachten 2010/11, Wiesbaden, Statistisches Bundesamt: p. 99 et seq.

Weiß, Wolfgang and Markus Haberkamm (2013): "Der ESM vor dem EuGH Widersprüchliche Wertungen in Luxemburg und Karlsruhe?”, Europäische Zeitschrift für Wirtschaftsrecht, (03): pp. 95-100.

Wetzel, Ralf Günther and Rauschning, Dietrich (1978), The Vienna Convention on the Law of Treaties, Frankfurt aM, Alfred Metzner Verlag.

Wiebel, Markus (1968), “Zur verwaltungsrechtlichen Bedeutung des Stabilitätsgesetzes”, Deutsches Verwaltungsblatt, 83 (22): pp. 899-904. 
Wieland, Jochen (2011): "Der Rettungsschirm für Irland”, Neue Zeitschrift für Verwaltungsrecht, (06): pp. 340-343.

Zeitler, Franz-Christoph (1995): "Die Europäische Währungsunion als Stabilitätsgemeinschaft”, Wertpapier-Mitteilungen, pp. 1609-1616.

Zilioli, Chiara (2005): "National Emergency Powers and Exclusive Community Competences - A Crack in the Dam?”, in: European Central Bank (ed), Liber Amicorum Paolo Zamboni Garavelli, Frankfurt aM, European Central Bank, pp. 115-134. 